\title{
Fluctuations of brown shrimp Crangon crangon abundance in the western Dutch Wadden Sea
}

\author{
Joana Campos, ${ }^{*, 1}{ }^{\text {, Ana Bio }}{ }^{1}$, Joana F. M. F. Cardoso ${ }^{1,2}$, Rob Dapper ${ }^{2}$, \\ Johannes I. J. Witte ${ }^{2}$, Henk W. van der Veer ${ }^{2}$ \\ ${ }^{1}$ CIMAR/CIIMAR, Centro Interdisciplinar de Investigação Marinha e Ambiental, Universidade do Porto, \\ Rua dos Bragas 289, 4050-123 Porto, Portugal \\ ${ }^{2}$ NIOZ, Royal Netherlands Institute for Sea Research, PO Box 59, 1790 AB Den Burg Texel, The Netherlands
}

\begin{abstract}
Long-term trends in brown shrimp Crangon crangon abundance were studied near the entrance of the Dutch Wadden Sea using a 34 yr time series of fyke net catches. A general trend of increasing abundance was observed. In autumn, brown shrimp abundance was 5 times greater than in spring, and interannual fluctuations were also more pronounced. Biotic and abiotic conditions showed effects with time lags of up to $1 \mathrm{yr}$, which is consistent with the species' life cycle. The population responded rapidly to changes in environmental conditions: abrupt declines after adverse conditions, as in spring 1999, were followed by steep recoveries in the following autumn. Two hypotheses were tested and discussed: (1) autumn recruitment is related to predator abundance and temperature during previous warmer seasons, and (2) overwintering adult abundance is determined by predation pressure and abiotic conditions in winter. In general, predator abundance was the main factor correlated to brown shrimp abundance, especially in autumn. Multiple linear regression modelling showed that predators altogether accounted for up to $55 \%$ in spring and up to $85 \%$ in autumn of the explained variance. Previous winter conditions such as sunshine duration, salinity and fresh water discharge, and the North Atlantic Oscillation Index (NAOI) were also correlated with autumn abundance. Yet, temperature conditions during the previous growing season did not determine the autumn stock size. Winter sunshine duration and the winter NAOI were correlated with spring stock size. Additionally, temperature and salinity were relevant factors affecting abundance during spring. A significant positive relationship between spring and autumn abundance and annual commercial landings was also found.
\end{abstract}

KEY WORDS: Long-term trends · Crangon crangon · Dutch Wadden Sea

\section{INTRODUCTION}

The brown or common shrimp Crangon crangon is one of the most abundant benthic species in shallow soft bottom areas along the European coast (Tiews 1970, Campos \& van der Veer 2008). Populations show a clear genetic structure, with distinct NE Atlantic and Mediterranean populations (Luttikhuizen et al. 2008). Due to its high abundance, C. crangon forms a key component of the trophic web: it is an important food source for several predators including fish, crustaceans and shorebirds (Pihl 1985, Henderson et al. 1992, del Norte-Campos \& Temming 1994, Walter \& Becker 1997) and, in turn, it preys heavily upon numerous benthic species such as bivalve spat and juvenile flatfish (Pihl \& Rosenberg 1984, van der Veer et al. 1991, 1998, Ansell \& Gibson 1993, Oh et al. 2001, Amara \& Paul 2003). In addition to its important ecological role, brown shrimp is a valuable fisheries resource, especially around the North Sea (Polet 2002, ICES 2008).

In the Dutch Wadden Sea, situated at intermediate latitude within the brown shrimp geographic distribution, egg-bearing females can be found all year round, although mainly in summer and winter (Boddeke \& Becker 1979, Boddeke 1982, Kuipers \& Dapper 1984). The summer generation might be subject to heavy predation pressure resulting in high mortality and low contribution to the fisheries standing stock (Kuipers \& 
Dapper 1984). In contrast, the larvae originating from winter eggs migrate into shallow nursery grounds where they settle in spring/summer (Boddeke \& Becker 1979, Boddeke et al. 1976, Feddersen 1993) and grow and increase in mass until autumn (Boddeke 1976, Kuipers \& Dapper 1984, Beukema 1992, Cattrijsse et al. 1997). Most shrimps reach maturity in the first autumn of life, migrate to overwintering grounds and are recruited into the commercial fishery. Part of the winter generation survives their first winter, returning to the nurseries the following spring when they again become available to the fishery. At this time, the new winter generation also appears (Kuipers \& Dapper 1984).

Despite these seasonal fluctuations, Crangon crangon is consistently highly abundant (Kuipers \& Dapper 1984, Beukema 1992) and hence recruitment, measured as the number of juveniles joining the reproductive population, must be highly successful almost every year. However, the processes underlying recruitment of C. crangon juveniles to the adult stock are not clearly understood. Food availability (Broekema 1942, Lloyd \& Yonge 1947, Beukema 1992), predation pressure (Cattrijsse et al. 1997) and environmental conditions such as water temperature (Ehrenbaum 1890, Havinga 1930, Boddeke 1975, Boddeke et al. 1976, Kuipers \& Dapper 1984, del Norte-Campos \& Temming 1998), salinity (Broekema 1942, Henderson \& Holmes 1987, Spaargaren 2000), light intensity or day length (Spaargaren 2000) and dissolved oxygen (Attrill et al. 1999) have been found to correlate with species recruitment.

A number of studies on the abundance of brown shrimp at intermediate latitude within its geographical distribution, based on extensive time series of respectively 12 (Attrill et al. 1999), 30 (Boddeke 1968, Driver 1976, Welleman \& Daan 2001) and 40 yr (Spaargaren 2000) suggested that predation pressure might be the most important source of mortality (Henderson \& Holmes 1989), though top-down control alone seems insufficient to explain recruitment regulation. In German waters, a $30 \mathrm{yr}$ study showed recently that the abundance of Crangon crangon in autumn was mainly influenced by river in-flow, winter water temperature and the Winter North Atlantic Oscillation Index (WNAOI) (Siegel et al. 2005). Nevertheless, none of these factors was found to influence brown shrimp abundance in spring (Siegel et al. 2005). In contrast, in the Bristol Channel, the number of recruits was found to be negatively correlated with the WNAOI in autumn and positively related to river run off and water temperature from January to August (Henderson et al. 2006). The severity of the winter and hence, winter temperature, has also been identified as a determinant for interannual oscillations in brown shrimp abun- dance: after severe winters, C. crangon abundance is much lower than beforehand. This is probably due to emigration to deeper (Beukema 1979) offshore waters (Boddeke 1975, 1976), causing later arrival of the new generation (Beukema 1992).

Following juvenile abundance is difficult due to their presence over large areas and their continuous emigration to deeper waters as they grow. Only a few studies provide reliable information on juvenile abundance (del Norte-Campos \& Temming 1998, Spaargaren 2000) and, therefore, to understand the key processes determining recruitment, we can presently only rely on available long-term data sets on adults. In the western Dutch Wadden Sea, near the island of Texel, a longterm fishing programme started in 1960. Fyke catches from this still ongoing project provide information on the abundance of adult brown shrimp and several of its predators. Seasonality in adult Crangon crangon abundance in this area is known to peak in spring and autumn (Spaargaren 2000), where autumn abundance represents emigration of mature shrimps towards overwintering grounds in the North Sea, and spring abundance corresponds to the immigration of adult shrimps returning to the shallow waters of the Wadden Sea after the winter (see Fig. 1). In the present study, we followed the approach of Spaargaren (2000), focussing on abundance of adult shrimps in spring and autumn. However, we expanded the analysis of Spaargaren until 2007, applying a thorough statistical analysis. For the first time, a $34 \mathrm{yr}$ time series of this area is studied in relation to a number of abiotic and biotic variables to understand the fluctuations of brown shrimp stocks over the course of time. The study site is particularly important because it is a turning point of passage between 2 areas of different ecological significance for the species: seawards, towards the overwintering areas in the North Sea; and inwards, towards the shallow nursery grounds of the Wadden Sea. Therefore, the aim of the present paper was to analyse which physical and biotic factors influence C. crangon's abundance and its seasonal and interannual fluctuations at the entrance of the Dutch Wadden Sea. The following hypotheses were defined:

(1) $H_{0}$ : The abundance of adults in autumn is determined by the abundance of predators and prevailing water temperature during the growing season.

(2) $H_{0}$ : The abundance of overwintering adults in spring is determined by predation pressure and environmental conditions during the winter.

The parameters used to test these hypotheses included predator abundance (as an indicator of predation pressure) and environmental variables which might reflect the seasonal conditions, such as water temperature, salinity, sunshine duration, daily precipitation, fresh water flow into the Wadden Sea and the North Atlantic Oscillation index (NAOI). Additionally, 
the relationship between brown shrimp autumn and spring abundances and its commercial landings was analysed.

\section{MATERIAL AND METHODS}

Biological time series. Monitoring started in 1960 near the southern part of Texel, de Hors, in the Marsdiep, at the entrance to the Dutch Wadden Sea (Fig. 1) and has been continued ever since. Fishing takes place using a passive trap of the fyke net type (Nédélec 1982). This 'fyke-kom' or 'kom-fyke' is a combination of a pound net and a fyke supported by wooden poles. It has a leader of $200 \mathrm{~m}$ running from above the high water mark into the subtidal region where 2 terminal chambers collect and catch fish and crustaceans (see Fig. 1 in van der Veer et al. 1992). The mesh-size of the leader and the 2 chambers is $10 \times 10 \mathrm{~mm}$. The tide in the area is dominated by the semidiurnal lunar tide and the tidal range varies between 1 and 2 m depending on conditions (neap versus spring tide, day versus night, weather conditions). Normally, tidal current speed in the fishing area does not exceed $1 \mathrm{~m} \mathrm{~s}^{-1}$, except for periods with strong wind stress.

During part of the winter, the kom-fyke is removed to avoid possible damage by ice floes and in summer, large amounts of jellyfish or macroalgae occasionally clog the net. Therefore, we focus mostly on 2 periods for which there is data for all the years: spring (between April and June) and autumn (between September and November). During these periods, the kom-fyke was usually emptied every morning from Monday to Friday irrespective of the tidal phase, except during bad weather conditions. When catches were low, the net was emptied every other morning. Only samples representing fishing periods of less than $48 \mathrm{~h}$ were considered for the present analysis following van der Meer et al. (1995), since longer periods may have resulted in net clogging or in losses due to decay or consumption (predation and cannibalism). Apart from wind and tidal influence, catching effort (during spring and autumn) can be considered constant. Therefore, fyke catches were assumed to reflect the species abundance.

All fyke net catches were sorted immediately and identified to species level. Individuals were counted for each species. However, when numbers were large, total wet mass was determined by species. Prior to data analysis, masses were transformed into counts using a fixed ratio, i.e. a fixed mean individual mass based on actual measurements (minimum 100 individuals). All information was stored in a database for further analysis. Information on daily abundance (individuals, ind. $\mathrm{d}^{-1}$ ) of brown shrimp (CRANG) and potential predators grouped at Order level were then extracted from the database and mean daily abundances were determined for each season (see below). The potential predators included Clupeiforms (CLUP), Gadiforms (GAD), Perciforms (PERC), Scorpaeniforms (SCORP), Pleuronectiforms (FLAT) and Decapods (CRAB) (Tiews 1970, De Vlas 1979, Pihl 1985, Henderson \& Holmes 1989, Henderson et al. 1992, Hamerlynck \& Hostens 1993, Berghahn 1996, Cattrijsse et al. 1997).

The present study was based on the data collected between 1974 and 2007, a period with consistent brown shrimp observations. To test the 2 hypotheses stated above, the respective response variables were defined as the brown shrimp abundance in autumn (representing adults emigrating towards the North Sea) which was determined as the mean catches from September to November, and the abundance in spring (representing immigrating adults, returning to the Wadden Sea from April) which was determined as the mean catches of April to June. Summer (July and August) and winter
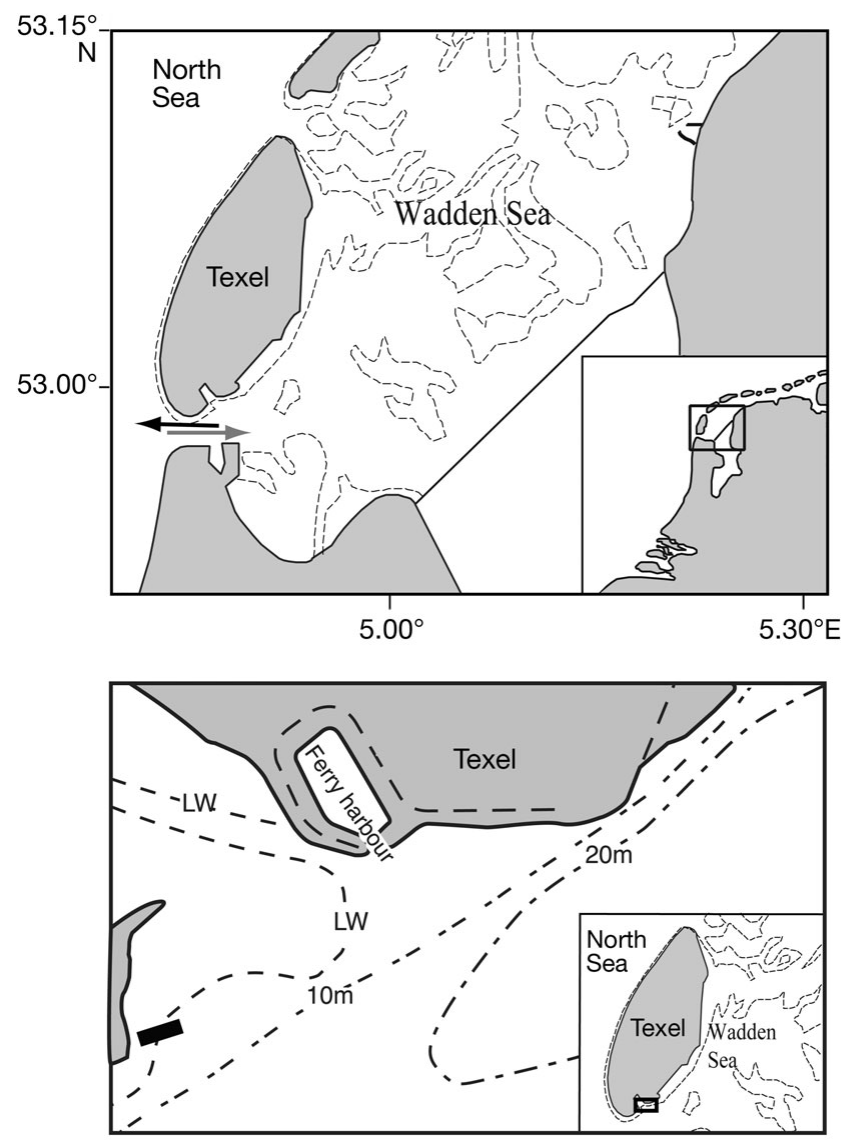

Fig. 1. Crangon crangon. Sampling location near the island of Texel (western Dutch Wadden Sea, The Netherlands). Upper panel: migration of adult shrimps. Inward $(\longrightarrow)$ to the Wadden Sea in spring, outward $(\longleftarrow)$ to the North Sea in autumn. Lower panel: fyke net position (black bar) at the entrance of Mok Bay. LW: low water mark 
(from December to March; only available for some months in 18 of the $34 \mathrm{yr}$ ) data were used as parameters to evaluate possible effects of past shrimp abundances on the 2 response variables. Spring and summer were considered as the growing seasons.

Environmental variables and indices. The environmental variables chosen reflect to some extent the season's conditions and included water temperature, salinity, sunshine duration, daily precipitation and Lake IJssel fresh water discharge into the Wadden Sea. Time series of water temperature $\left({ }^{\circ} \mathrm{C}\right.$ ) (van Aken 2008a) and salinity (van Aken 2008b) at the Marsdiep area, Texel, were available for the entire monitoring period. Seasonal temperature and salinity were determined by averaging respective monthly means, over the same seasons as for the biological data.

The NAOI, which reflects the large-scale pattern of climate variability in the North Atlantic Ocean, is determined by the difference between the normalised sea level air pressure between the Azores and Iceland (Jones et al. 1997) and was also used as a variable in the analysis. NAOI data was taken from the NOAA/National Weather Service (www.cpc.noaa.gov/index.php). The WNAOI and extended WNAOI were determined as the average NAOI from January to March and December to March, respectively. An average spring and autumn NAOI was also calculated with data from April to June and September to November, respectively. Meteorological information, which included sunshine duration (SUN, $0.1 \mathrm{~h}$ ) and total daily precipitation (DAYPREC, $0.1 \mathrm{~mm}$ ) was obtained from the Royal Netherlands Meteorological Institute. Data on the Lake IJssel fresh water out-flow (DEBIET, $\mathrm{m}^{3} \mathrm{~s}^{-1}$ ) into the western Wadden Sea at the Afsluitdijk area was obtained from van der Hoeven (1982) for the period 1960 to 1975 and from Rijkswaterstaat for the period 1976 to 2007.

For the period 1973 to 1994, annual commercial brown shrimp landings (LANDINGS, t) from the North Sea were obtained from producer organisations (I. Tulp pers. comm.) and for the period 1995 to 2007, the information was taken from the logbooks of the Dutch fleet (VIRIS data base; Dutch Ministry of Agriculture, Nature and Food Quality), which until 2003 also included landings in foreign harbours.

Data analysis. Data were log-transformed, if necessary, to achieve approximate normal distributions. General trend, seasonal trend and serial correlation in the spring and autumn shrimp catch data were analysed by means of an autoregressive moving average (ARMA) $(p, q)$ time-series model (Brockwell \& Davis 1996). To fit the ARMA noise model, the sequence of observations has to constitute a weakly stationary process, i.e. a process with constant mean and variance. If necessary, data have to be transformed first in order to achieve stationarity. The noise model was chosen by examining the sample and residual autocorrelation functions (ACF) and partial autocorrelation functions (PACF), and model parameters were estimated. The best of a series of alternative model complexities was selected based on the minimum biased-corrected Akaike's information criterion $\mathrm{AIC}_{\mathrm{C}}$ (Hurvich \& Tsai 1989). For a detailed description of the ARMA modelling steps see Chapter 5 of Brockwell \& Davis (1996).

A possible effect of previous brown shrimp abundances on seasonal observations was studied for the spring and autumn data sets separately. Analysing series of data from the same season, only long-term temporal relationships (yearly lags) could be examined. To assess medium-term seasonal effects, correlations with variables from previous seasons were also computed. Therefore, spring and autumn shrimp abundances were also correlated to biotic and abiotic data from previous seasons, allowing assessment of the effects of past population (previous seasons' shrimp data) and predator or environmental conditions.

Cross-correlations between the seasonal shrimp abundances and abundances in the preceding spring and autumn seasons were computed. Cross-correlations were also computed for the seasonal shrimp abundances and other biological (predator abundances) and environmental variables. This analysis not only provided correlation values for time series but also showed possible temporal delay in correlation. Correlations were computed for all biological and environmental variables. A list of these variables and their main statistics can be found in Appendix 1.

The influence of one or more different biotic and abiotic variables on brown shrimp abundances in spring and autumn was studied through multiple linear regression modelling (McCullagh \& Nelder 1983). The functions relate spring or autumn shrimp abundances as response variable with seasonal predator abundances and seasonal environmental conditions. To test the hypotheses mentioned above, including possible delayed responses of shrimp abundances to the predictor variables, the latter were taken from the response period and from previous seasons. Analysis for shrimp spring abundances considered: (1) shrimp data from the previous autumn and the previous spring; (2) predator and (3) environmental data from the same period as the response variable, from the previous winter (when available) and the previous autumn (see Appendix 1). Analysis for shrimp autumn abundances considered: (1) shrimp data from the previous spring and the previous autumn, as well as (2) predator and (3) environmental data from the same period as the response variable, from the previous winter (when available), the previous summer and previous spring. Since biological winter data were scarce (only avail- 
able for 18 yr), 2 subsets were considered for each season: one considering only data available for the whole sampling period, and a second including shrimp and predator winter data but consequently with less observations. Interaction terms were not considered to keep the number of predictor terms manageable and model selection straightforward.

To avoid the pitfalls of stepwise model selection, we performed an allsubsets regression (Miller 2002) calculating models with all possible combinations of a given size (i.e. including 1 predictor, 2 predictors, etc.). Considering sample sizes, we tested models with up to 10 predictors for the first

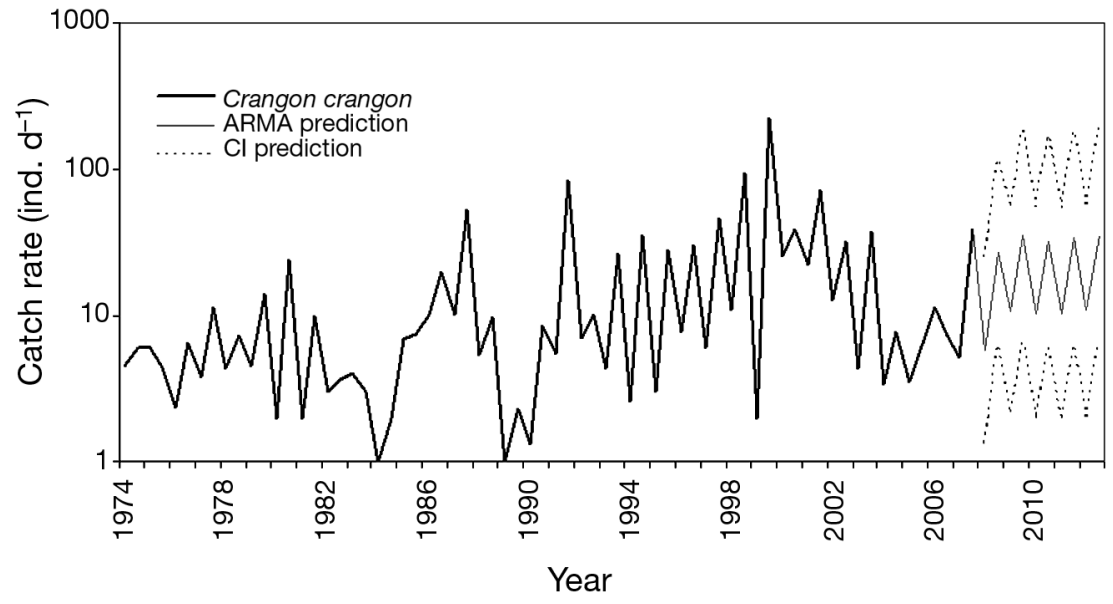

Fig. 2. Crangon crangon. Observed mean spring and autumn catch rate in the Dutch Wadden Sea and autoregressive moving average (ARMA) forecast (logarithmic $y$-axis) with $95 \%$ confidence intervals (CI) dataset $(\mathrm{n}=34$ ) and with up to 7 predictors for the second $(\mathrm{n}=18)$. The best 2 models of each size were submitted to leaveone-out cross-validation to aid model choice. Final models were chosen aiming at maximum parsimony and minimum cross-validation error, as well as inclusion of consistently chosen predictor variables. The relative importance of each predictor variable was determined by averaging sequential sums of squares over all orderings of regressors (Lindeman et al. 1980). Residuals were tested for normality and for autocorrelation.

Time-series analysis was undertaken in ITSM (Interactive Time Series Modelling, Hyndman 1994) and all other statistical analyses were performed using $\mathrm{R}(\mathrm{R}$ Development Core Team 2005).

\section{RESULTS}

\section{Seasonal and inter-annual variability in shrimp abundance}

In autumn brown shrimp abundance in the Wadden Sea was approximately 5 times (mean abundance) or 3 times (median abundance) higher than in spring (Fig. 2, Appendix 1). Maximum abundance in spring occurred in 2000 (25 ind. $\left.\mathrm{d}^{-1}\right)$, with peaks in 1986, 1987 (10 ind. $\mathrm{d}^{-1}$ in both years), 1998 (11 ind. $\left.\mathrm{d}^{-1}\right), 2001$ (22 ind. $\mathrm{d}^{-1}$ ), 2002 (13 ind. $\mathrm{d}^{-1}$ ) and 2006 (12 ind. $\mathrm{d}^{-1}$ ). The highest catch in autumn was observed in 1999, reaching 220 ind. $\mathrm{d}^{-1}$ on average. Other peak abundances were observed in 1987 (52 ind. $\mathrm{d}^{-1}$ ), 1991 (84 ind. $\left.\mathrm{d}^{-1}\right), 1998$ (94 ind. $\mathrm{d}^{-1}$ ) and 2001 (72 ind. $\left.\mathrm{d}^{-1}\right)$. Minimum spring abundance occurred in 1984 when no brown shrimps were captured. However, spring abundance was in general very low (6.1 ind. $\mathrm{d}^{-1}$ on average)

and average values of $<4$ ind. $\mathrm{d}^{-1}$ were detected in several years $(1976,1977,1980$ to $1983,1989,1990,1994$, 1995, 1999, 2004 and 2005). The lowest autumn abundance recorded was also in $1984\left(0\right.$ ind. $\left.\mathrm{d}^{-1}\right)$ with low values continuing for the following $2 \mathrm{yr}$.

The shrimp abundance data series showed an increasing trend, particularly until the early 2000s (Linear regression model 1975 to 2000: $\mathrm{p}=0.001$, adjusted $\mathrm{R}^{2} 0.17$; 1975 to 2007: $\mathrm{p}=0.003$, adjusted $\mathrm{R}^{2} 0.12$ ), and a seasonal component reflecting the differences between spring and autumn. The linear trend and seasonal component were fitted to the transformed data using ordinary least-squares. The resulting linear trend for the log-abundances $S(t)=0.0196 t+1.4864(t$, time in half yr periods), corresponds to an average increase of 1.02 ind. $\mathrm{d}^{-1} \mathrm{yr}^{-1}$ for untransformed abundances. The seasonal components were -0.58277 and 0.58277 for spring and autumn, respectively. The residual ACF and PACF (Fig. 3) obtained after the linear trend and the seasonal signal were subtracted from the data and showed that an ARMA $(2,2)$ model fitted the data well. This means that only data from the previous year (1 spring and 1 autumn season) had a significant correlation with each observation. The obtained residual ARMA model was:

$$
\begin{aligned}
X(t)= & 0.6176 X(t-1)-0.3665 X(t-2)+Z(t) \\
& -0.5617 Z(t-1)+0.8028 Z(t-2)
\end{aligned}
$$

with a white-noise variance of 0.5586 and an accuracy parameter of 0.0012. A forecast for the $5 \mathrm{yr}$ following the sample period (Fig. 2) shows the increasing trend and the forecast uncertainty.

The positive correlation between shrimp abundances and those observed during the previous year, found in the time-series analysis was also found in the 


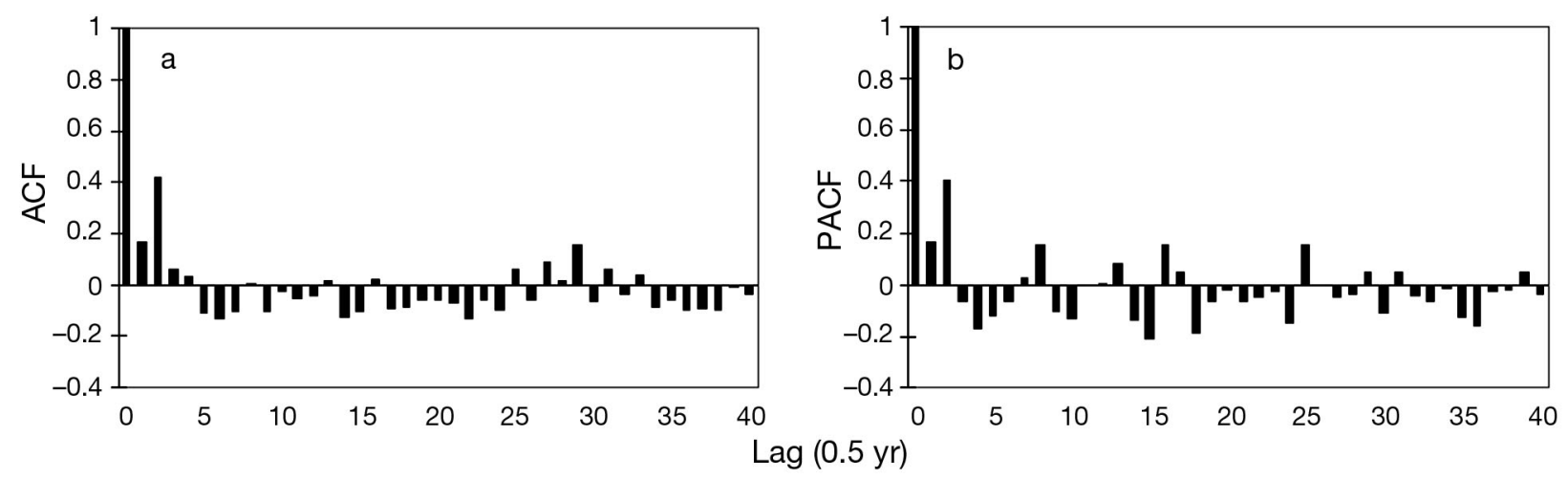

Fig. 3. Crangon crangon. (a) Auto-correlation function (ACF) and (b) partial autocorrelation function (PACF) with half-year lags, after subtracting the linear trend and the seasonal signal from C. crangon abundance in the Dutch Wadden Sea

correlation analyses (Table 1). Autumn abundance was significantly positively correlated to that of the previous autumn and to a lesser degree to that of the previous spring. Spring abundance was significantly positively correlated to that of the previous autumn. Note that all analyses were performed on log-transformed shrimp abundances.

\section{Relationship between shrimp abundance, predators and environmental variables}

The natural logarithm was taken for all biological data (shrimp and predators abundance), since this transformation normalised these data adequately. Environmental data did not need to be transformed. Cross-correlations relating (log-transformed) shrimp data to (log-transformed) predator data and (nontransformed) environmental variables are presented in Table 1, including significant correlations for non-zero lags. In terms of predators, spring shrimp abundances were significantly positively correlated with Clupeiforms and negatively correlated with Decapods. Autumn shrimp abundances were also significantly positively correlated with the season's Clupeiform and Perciform abundances, next to the Clupeiforms in the previous spring. Furthermore, there was a significant negative correlation with Scorpaeniform and Pleuronectiform abundances measured $2 \mathrm{yr}$ before. Both spring and autumn shrimp data were positively correlated to landings and to sunshine duration of the previous winter. Spring data were furthermore positively correlated with autumn water temperature, whereas autumn data showed a negative correlation with the winter out-flow from Lake IJssel. Cross-correlation functions (CCF) could not be calculated for winter biotic data due to the incomplete time series. Time series of the spring, autumn and winter (when available) data of the most relevant variables are shown in Fig. 4.
Many of the considered independent variables were significantly ( $\alpha=0.05$ ) correlated. For both spring and autumn data sets, the highest correlations were found among abiotic variables. In the spring data, significant, positive correlations were found among: TEMP, NAOI, WNAOI and exWNAOI; and TEMP, SUN and LANDINGS. SAL was negatively correlated with DAYPREC, DEBIET and LANDINGS. For the autumn data set, there were positive correlations between: NAOI and exWNAOI; DEBIET and DAYPREC; and LANDINGS and SUN. Negative correlations were found between DEBIET and TEMP; SAL and SUN; and DAYPREC and SUN.

For the spring-data predators, positive correlations were found among: SCORP, GAD and PERC; PERC and FLAT; GAD, winter SCORP and FLAT; PERC, winter PERC and CRAB; SCORP, winter GAD and FLAT; and FLAT, winter FLAT and CRAB. There were also positive correlations with predators from the previous autumn, i.e. between SCORP and autumn GAD; SCORP and FLAT; and CRAB and autumn CRAB. Negative correlations were found between: SCORP and autumn CLUP; and among FLAT, autumn CLUP and PERC.

For the autumn-data predators, there were significant positive correlations among: GAD, SCORP and FLAT; SCORP and PERC; CLUP and summer CLUP; GAD and spring and winter FLAT; summer GAD and PERC; SCORP and spring SCORP; summer GAD and PERC; winter CLUP, GAD, SCORP and FLAT; FLAT, spring GAD and SCORP; summer GAD and PERC; winter CLUP, GAD, SCORP and FLAT; and CRAB, spring CLUP and summer CRAB. Negative correlations were found between: CLUP and SCORP; summer and winter GAD, and summer FLAT; and SCORP and summer CLUP.

Spring GAD, PERC and SCORP were positively correlated with DEBIET; GAD was negatively correlated with WNAOI, and SCORP with TEMP and SUN. Autumn GAD, SCORP and FLAT were negatively correlated with LANDINGS. GAD and SCORP were posi- 
tively correlated with DAYPREC and DEBIET, and negatively with SUN. GAD and FLAT were positively correlated with NAOI, yet negatively with WNAOI. CRAB was negatively correlated with SAL.

Table 1. Crangon crangon. Cross-correlation (CC) results (Pearson correlation) of spring and autumn abundances with environmental variables from the current season (no lower case letter), and with predators and environmental variables from previous autumn (a), spring (s), summer (sm) and winter (w) seasons; codes according to Appendix 1. Whenever correlation was highest and significant for a non-zero lag, this lag and its correlation is also mentioned (Maximum lag, CC). Significant correlations are printed in bold; variables selected in the final multiple linear regression models $(\mathrm{LM})$ are given $(1=$ model considering variables available for the whole time series, 34 samples; $2=$ model including winter variables, restricted to 18 samples)

\begin{tabular}{|c|c|c|c|c|c|c|c|}
\hline \multirow[t]{3}{*}{ Variable } & \multirow{3}{*}{$\begin{array}{l}\text { Zero-lag } \\
\text { CC }\end{array}$} & \multicolumn{2}{|c|}{ Spring - } & \multirow{3}{*}{$\begin{array}{l}\text { Zero-lag } \\
\text { CC }\end{array}$} & \multicolumn{2}{|c|}{ - Autumn - } & \multirow{3}{*}{ LM } \\
\hline & & LM & Variable & & \multicolumn{2}{|c|}{ Maximum } & \\
\hline & & & & & lag & $\mathrm{CC}$ & \\
\hline CRANGa & 0.400 & 1 & CRANGs & 0.439 & & & \\
\hline CRANGs & 0.249 & & CRANGa & 0.582 & & & \\
\hline CLUP & 0.390 & & CLUP & 0.368 & & & \\
\hline GAD & -0.181 & & GAD & -0.334 & & & \\
\hline PERC & 0.222 & 1 & PERC & 0.512 & & & 1,2 \\
\hline SCORP & -0.218 & & SCORP & -0.230 & & & \\
\hline FLAT & -0.111 & & FLAT & -0.180 & 1 & -0.326 & \\
\hline CRAB & -0.432 & & CRAB & 0.080 & & & \\
\hline TEMP & 0.048 & 1 & TEMP & 0.002 & & & \\
\hline SAL & -0.232 & & SAL & -0.251 & & & \\
\hline SUN & -0.011 & & SUN & 0.222 & & & \\
\hline DAYPREC & 0.038 & & DAYPREC & 0.013 & & & \\
\hline DEBIET & 0.221 & & DEBIET & 0.065 & & & \\
\hline CLUPa & -0.555 & & CLUPs & 0.499 & & & 1 \\
\hline GADa & -0.297 & 1 & GADs & -0.214 & & & \\
\hline PERCa & 0.229 & 2 & PERCs & 0.040 & & & \\
\hline SCORPa & -0.234 & 2 & SCORPs & -0.334 & & & \\
\hline FLATa & -0.201 & & FLATs & -0.234 & & & \\
\hline CRABa & -0.086 & & CRABs & -0.241 & 2 & -0.578 & \\
\hline TEMPa & 0.419 & 1 & TEMPs & 0.276 & & & \\
\hline SALa & 0.091 & 2 & SALs & -0.061 & & & \\
\hline SUNa & 0.129 & & SUNs & 0.108 & & & \\
\hline DAYPRECa & 0.025 & & DAYPRECs & 0.142 & & & \\
\hline DEBIETa & -0.035 & & DEBIETs & 0.055 & & & \\
\hline TEMPw & -0.039 & & TEMPw & 0.002 & & & \\
\hline SALw & -0.073 & & SALw & 0.105 & & & 1 \\
\hline SUNw & 0.392 & & SUNw & 0.418 & & & \\
\hline DAYPRECW & -0.045 & & DAYPRECW & -0.074 & & & \\
\hline DEBIETw & -0.130 & & DEBIETw & -0.373 & & & 1 \\
\hline & & & CLUPsm & 0.205 & & & 1,2 \\
\hline & & & GADsm & -0.099 & & & \\
\hline & & & PERCsm & -0.070 & & & \\
\hline & & & SCORPsm & -0.103 & & & \\
\hline & & & FLATsm & -0.057 & & & \\
\hline & & & CRABsm & 0.142 & 1 & 0.458 & \\
\hline & & & TEMPsm & 0.223 & & & \\
\hline & & & SALsm & -0.184 & & & \\
\hline & & & SUNsm & 0.084 & & & \\
\hline & & & DAYPRECsm & 0.015 & & & \\
\hline & & & DEBIETsm & 0.031 & & & \\
\hline LANDINGS & 0.398 & & LANDINGS & 0.465 & & & \\
\hline NAOI & -0.051 & & NAOI & -0.173 & & & 2 \\
\hline WNAOI & -0.039 & 2 & WNAOI & 0.218 & & & \\
\hline exWNAOI & -0.046 & & exWNAOI & 0.017 & & & \\
\hline
\end{tabular}

\section{Regression models}

The 2 best models for each subset of predictor variables for the Crangon crangon spring and autumn abundances are presented in Table $2 \mathrm{a} \& \mathrm{~b}$, respectively. Based on the sample size and the cross-validation error and its evolution with increasing model complexity, the following 5-predictor model for the complete series of spring data was chosen:

$$
\begin{aligned}
& \log (\text { CRANG })=1.465+0.313 \log \\
& (\text { CRANGa })+0.878 \log (\text { PERC }) \\
& -0.386 \text { TEMP }-0.611 \log (\text { GADa }) \\
& +0.312 \text { TEMPa }
\end{aligned}
$$

with CRANG and CRANGa representing $C$. crangon abundance in spring and in the previous autumn, respectively, PERC the abundance of Perciforms, TEMP spring water temperature, GADa the abundance of Gadiforms in the previous autumn and TEMPa water temperature in the previous autumn. All model terms were significant $(\alpha=0.05)$. The model explains $56.9 \%$ of the variance, with CRANGa accounting for $32 \%$, TEMPa for $27 \%$, GADa for $15 \%$, PERC for $14 \%$ and TEMP for $12 \%$ of the explained variance.

For the autumn data the following model was selected:

$\log ($ CRANG $)=9.588+2.265 \log$

$(\mathrm{PERC})+0.321 \log (\mathrm{CLUPs})$

$+0.172 \log ($ CLUPsm $)-0.438$ SALw

- 0.003 DEBIETw

with CRANG representing Crangon crangon abundance in the current autumn, PERC the abundance of Perciforms, CLUPs and CLUPsm the abundance of Clupeiforms in the previous spring and summer, respectively, and SALw and DEBIETw the salinity and discharge from Lake IJssel into the Wadden Sea in the previous winter. All model terms were significant $(\alpha=$ 0.05). The model explains $79.0 \%$ of the variance, with PERC accounting for $39 \%$, CLUPs and CLUPsm for $17 \%$ each, SALw for $16 \%$ and DEBIETw for $11 \%$ of the explained variance.

Model residuals were approximately normally distributed and did 
not present significant temporal autocorrelation (Fig. 5), suggesting that model parameters account for the autocorrelation found in the seasonal brown shrimp abundance data. Regression model predictions correlate closely with the measured abundances (Fig. 6).
When also considering winter shrimp and fish data as candidate predictor variables, and thereforeonly 18 sample years, the selected spring model was: $\log ($ CRANG $)=-6.766+2.253 \log ($ PERCa $)-1.068$ $\log (\mathrm{SCORPa})+0.199 \mathrm{SALa}-0.913 \mathrm{WNAOI}$

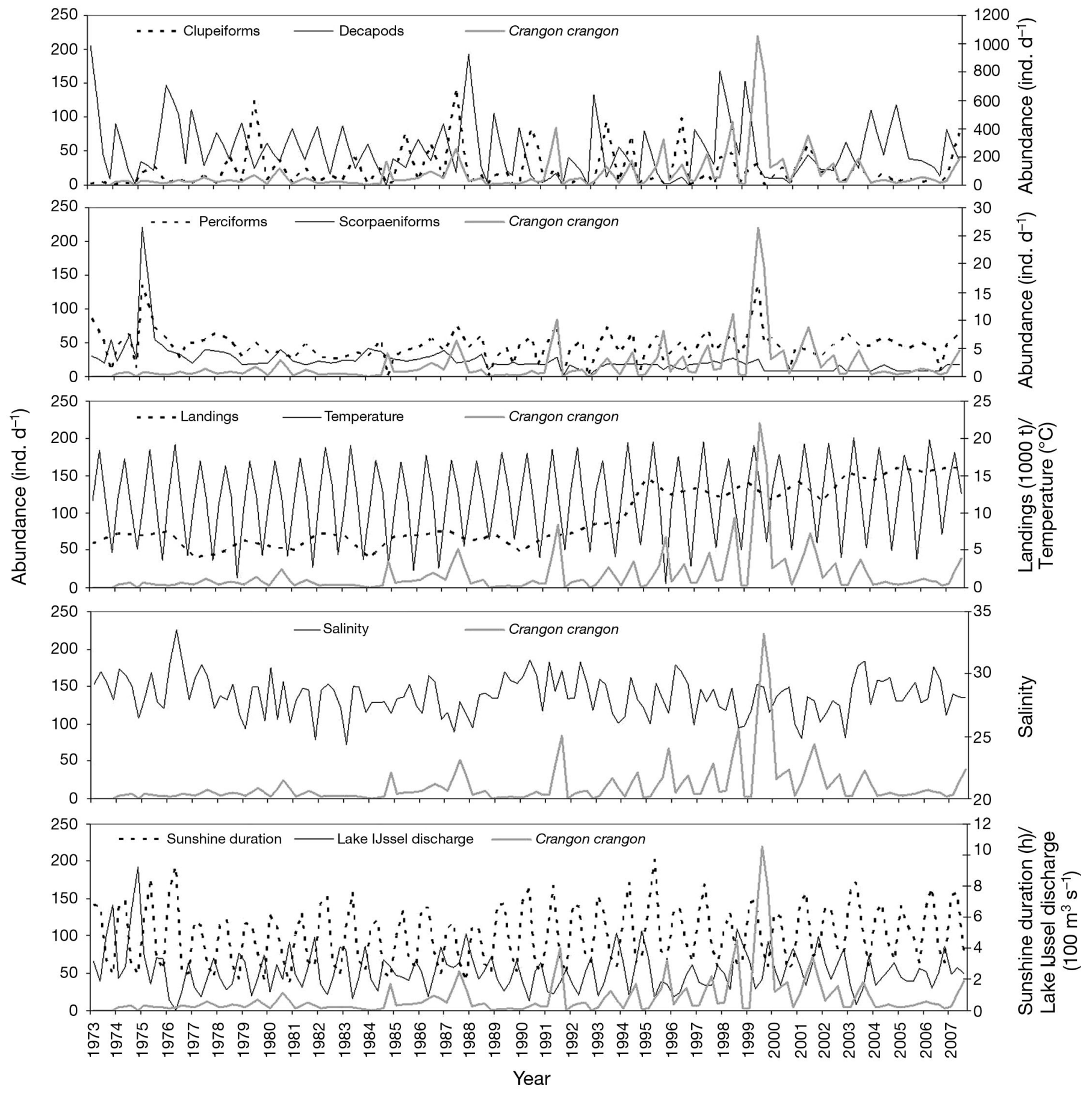

Fig. 4. Time series of the spring, autumn and winter (when available) abundance of Crangon crangon (left axis), Clupeiforms, Decapods, Perciforms and Scorpaeniforms in the Dutch Wadden Sea, and annual North Sea commercial landings of C. crangon $(1000 \mathrm{t})$, water temperature $\left({ }^{\circ} \mathrm{C}\right)$, salinity, sunshine duration $(\mathrm{h})$ and freshwater discharge from Lake IJssel into the Wadden Sea $\left(100 \mathrm{~m}^{3} \mathrm{~s}^{-1}\right)$ 
with CRANG representing spring Crangon crangon abundance, PERCa and SCORPa the densities of Perciforms and Scorpaeniforms of the previous autumn, SALa the salinity of the previous autumn and WNAOI the NAOI of the previous winter. All model terms were significant $(\alpha=0.05)$. The model explains $79.5 \%$ of the variance, with PERCa accounting for $39 \%$, WNAOI for $38 \%$, SCORPa for $16 \%$ and SALa for $7 \%$ of the explained variance.

The autumn model was:

$\log ($ CRANG $)=-5.746+2.920 \log ($ PERC $)+0.542$

$\log ($ CLUPsm $)+0.433 \log ($ PERCw $)-1.060$ NAOI with CRANG representing autumn Crangon crangon abundances, PERC and PERCw autumn and previous winter Perciforms abundance, respectively, CLUPsm abundance of Clupeiforms in the previous summer and NAOI autumn NAOI. All model terms were significant ( $\alpha=0.01$ ). The model explains $90.9 \%$ of the variance, with CLUPsm accounting for 36\%, PERC for 33\%, PERCW for $16 \%$ and NAOI for $15 \%$ of the explained variance.

The regression model selection procedure prevented inclusion of strongly correlated variables into one model. Given the data sets used and the selected models, only the spring model excluding winter biotic vari-

Table 2. The 2 best regression models each with 1 to 10 parameters (df), for the (a) spring and (b) autumn data excluding biotic winter variables $(n=34)$, their model terms, multiple $\mathrm{R}^{2}$, leave-one-out cross-validation error $(\mathrm{CV})$ and $\mathrm{p}$-value; model terms are superscripted according to their significance $\left(0.001^{* *}, 0.01^{* *}, 0.05^{*}, 0.1^{\bullet}\right.$ and $\left.>0.1^{-}\right)$; the selected model is printed in bold; codes according to Appendix 1 and Table 1

\begin{tabular}{|c|c|c|c|c|}
\hline & f Model terms & $\mathrm{R}^{2}$ & $\mathrm{CV}$ & p-value \\
\hline \multicolumn{5}{|c|}{ a) Spring } \\
\hline & $\begin{array}{l}\text { TEMPa } \\
\text { CRAB* }\end{array}$ & $\begin{array}{l}0.175 \\
0.186\end{array}$ & $\begin{array}{l}0.407 \\
0.415\end{array}$ & $\begin{array}{l}0.0137 \\
0.0108\end{array}$ \\
\hline & $\begin{array}{l}\text { CRAB }{ }^{* *}+\mathrm{SAL}^{*} \\
\text { CRANGa*+TEMPa** }\end{array}$ & $\begin{array}{l}0.299 \\
0.323\end{array}$ & $\begin{array}{l}0.361 \\
0.359\end{array}$ & $\begin{array}{l}0.0040 \\
0.0023\end{array}$ \\
\hline & $\begin{array}{l}\text { CRANGa }^{* *}+\text { TEMPa }^{*}+\text { WNAOI }^{*} \\
\text { CRANGa }^{* *}+\text { TEMP }^{*}+\text { TEMPa }^{* *}\end{array}$ & $\begin{array}{l}0.407 \\
0.408\end{array}$ & $\begin{array}{l}0.335 \\
0.335\end{array}$ & $\begin{array}{l}0.0012 \\
0.0012\end{array}$ \\
\hline & $\begin{array}{l}\text { CRANGa }^{* * *}+\text { TEMP }^{*}+\mathrm{CLUPa}^{*}+\mathrm{TEMPa}^{* *} \\
\text { CLUP }^{*}+\mathrm{PERCa}^{* *}+\mathrm{TEMPa}^{* *}+\mathrm{exWNAOI}^{*}\end{array}$ & $\begin{array}{l}0.479 \\
0.479\end{array}$ & $\begin{array}{l}0.305 \\
0.327\end{array}$ & $\begin{array}{l}0.0006 \\
0.0006\end{array}$ \\
\hline 5 & $\begin{array}{l}\text { CRANGa }^{* * *}+\text { PERC C }^{* *}+\text { TEMP }^{* *}+\text { GADa }^{*}+\text { TEMPa }^{* *} \\
\text { CLUP }^{*}+\text { GAD }^{*}+\text { PERCa }^{* *}+\text { TEMPa }^{* *}+\text { exWNAOI }^{* *}\end{array}$ & $\begin{array}{l}\mathbf{0 . 5 6 9} \\
0.570\end{array}$ & $\begin{array}{l}\mathbf{0 . 2 7 0} \\
0.279\end{array}$ & $\begin{array}{l}0.0002 \\
0.0001\end{array}$ \\
\hline 7 & $\begin{array}{l}\mathrm{CRAB}^{* *}+\mathrm{SAL}^{* *}+\mathrm{GADa}^{* *}+\mathrm{PERCa}^{* *}+\mathrm{SALa}^{*}+\mathrm{exWNAOI}{ }^{* *} \\
\text { CRAB }^{*}+\mathrm{DEBIET}^{* *}+\mathrm{GADa}^{* *}+\mathrm{PERCa}^{* *}+\mathrm{SALa}^{*}+\mathrm{exWNAOI}^{* *}\end{array}$ & $\begin{array}{l}0.618 \\
0.620\end{array}$ & $\begin{array}{l}0.281 \\
0.283\end{array}$ & $\begin{array}{l}0.0001 \\
0.0000\end{array}$ \\
\hline 6 & $\begin{array}{l}\mathrm{CRAB}^{*}+\mathrm{DEBIET}^{* * *}+\mathrm{SUNW}^{*}+\mathrm{GADa}^{* *}+\mathrm{PERCa}^{* *}+\mathrm{SALa}^{* *}+\mathrm{exWNAOI}^{* * *} \\
\text { CRANGs }^{*}+\mathrm{CRAB}^{* *}+\mathrm{DEBIET}^{* *}+\mathrm{GADa}^{* *}+\mathrm{PERCa}^{* *}+\mathrm{SALa}^{*}+\mathrm{exWNAOI}^{* *}\end{array}$ & $\begin{array}{l}0.674 \\
0.683\end{array}$ & $\begin{array}{l}0.261 \\
0.258\end{array}$ & $\begin{array}{l}0.0000 \\
0.0000\end{array}$ \\
\hline 8 & $\begin{array}{l}\text { FLAT }^{*}+\mathrm{CRAB}^{* *}+\mathrm{DEBIET}^{* * *}+\mathrm{SUNW}^{*}+\mathrm{GADa}^{* *}+\mathrm{PERCa}^{* * *}+\mathrm{SALa}^{* *}+\operatorname{exWNAOI} \mathrm{PLO}^{* *} \\
\text { CLUP }^{*}+\mathrm{CRAB}^{*}+\mathrm{SAL}^{* *}+\mathrm{DAYPREC}^{*}+\mathrm{GADa}^{* *}+\mathrm{PERCa}^{* * *}+\mathrm{SALa}^{* *}+\mathrm{exWNAOI}^{* *}\end{array}$ & $\begin{array}{l}0.714 \\
0.715\end{array}$ & $\begin{array}{l}0.239 \\
0.247\end{array}$ & $\begin{array}{l}0.0000 \\
0.0000\end{array}$ \\
\hline 9 & $\begin{array}{l}\text { CLUP }^{*}+\mathrm{CRAB}^{*}+\mathrm{SAL}^{* * *}+\mathrm{DAYPREC}^{*}+\mathrm{SUNw}^{-}+\mathrm{GADa}^{*}+\mathrm{PERCa}^{* * *}+\mathrm{SALa}^{* *}+\mathrm{exWNAOI}^{* *} \\
\text { FLAT }^{*}+\mathrm{CRAB}^{* *}+\mathrm{DEBIET}^{* * *}+\mathrm{SUNW}^{* *}+\mathrm{GADa}^{* *}+\mathrm{PERCa}^{* * *}+\mathrm{SALa}^{* * *}+\mathrm{LANDINGS}^{-+}+\mathrm{exWNAOI}^{* * *}\end{array}$ & $\begin{array}{l}0.742 \\
0.743\end{array}$ & $\begin{array}{l}0.241 \\
0.230\end{array}$ & $\begin{array}{l}0.0000 \\
0.0000\end{array}$ \\
\hline & 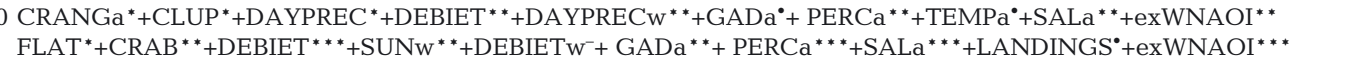 & $\begin{array}{l}0.767 \\
0.768\end{array}$ & $\begin{array}{l}0.225 \\
0.219\end{array}$ & 0.0000 \\
\hline \multicolumn{5}{|c|}{ b) Autumn } \\
\hline & $\begin{array}{l}\text { PERC }^{* *} \\
\text { CRANGa*** }\end{array}$ & $\begin{array}{l}0.262 \\
0.339\end{array}$ & $\begin{array}{l}0.902 \\
0.806\end{array}$ & $\begin{array}{l}0.0020 \\
0.0003\end{array}$ \\
\hline 2 & $\begin{array}{l}\text { PERC }^{* * *}+\text { CLUPsm }^{* *} \\
\text { CRANGa }^{* * *}+\text { PERC }^{* *}\end{array}$ & $\begin{array}{l}0.495 \\
0.513\end{array}$ & $\begin{array}{l}0.707 \\
0.613\end{array}$ & $\begin{array}{l}0.0000 \\
0.0000\end{array}$ \\
\hline 3 & $\begin{array}{l}\text { PERC }^{* * *}+\text { SALW }^{* * *}+\text { DEBIETw }^{* *} \\
\text { PERC }^{* * *}+\text { CLUPS }^{* * *}+\text { SCORPs } \\
* * *\end{array}$ & $\begin{array}{l}0.538 \\
0.643\end{array}$ & $\begin{array}{l}0.618 \\
0.507\end{array}$ & $\begin{array}{l}0.0000 \\
0.0000\end{array}$ \\
\hline 4 & $\begin{array}{l}\text { PERC }^{* * *}+\text { CLUPsm }^{* *}+\text { SALW }^{* * *}+\text { DEBIETW }^{* *} \\
\text { PERC }^{* * *}+\text { CLUPS }^{* * *}+\text { SALw }^{* *}+\text { DEBIETw }^{* * *}\end{array}$ & $\begin{array}{l}0.735 \\
0.686\end{array}$ & $\begin{array}{l}0.405 \\
0.501\end{array}$ & $\begin{array}{l}0.0000 \\
0.0000\end{array}$ \\
\hline 5 & $\begin{array}{l}\text { CRANGs }^{* *}+\text { PERC }^{* * *}+\text { CLUPS }^{*}+\text { SALW }^{* *}+\text { DEBIETw }^{* * *} \\
\text { PERC }^{* * *}+\text { CLUPs }^{*}+\text { CLUPsm }^{*}+\text { SALw }^{* * *}+\text { DEBIETw } \\
* * *\end{array}$ & $\begin{array}{l}0.770 \\
\mathbf{0 . 7 9 0}\end{array}$ & $\begin{array}{l}0.425 \\
\mathbf{0 . 3 7 0}\end{array}$ & $\begin{array}{l}0.0000 \\
0.0000\end{array}$ \\
\hline 6 & $\begin{array}{l}\text { CRANGs }^{* * *}+\text { PERC }^{* * *}+\text { SUNSm }^{*}+\mathrm{SALw}^{* * *}+\mathrm{DAYPRECW}^{* *}+\mathrm{DEBIETW}^{* * *} \\
\text { PERC } \\
\text { PER }^{* *}+\mathrm{CLUPS}^{*}+\mathrm{FLATs}^{*}+\mathrm{CLUPSm}^{* *}+\mathrm{SALw}^{* * *}+\mathrm{DEBIETw}^{* * *}\end{array}$ & $\begin{array}{l}0.819 \\
0.831\end{array}$ & $\begin{array}{l}0.320 \\
0.302\end{array}$ & $\begin{array}{l}0.0000 \\
0.0000\end{array}$ \\
\hline 7 & $\begin{array}{l}\text { CRANGs }^{* * *}+\text {PERC }^{* * *}+\mathrm{DEBIETS}^{*}+\mathrm{SUNsm}^{* *}+\mathrm{SALw}^{* * *}+\mathrm{DAYPRECW}^{* * *}+\mathrm{DEBIETW}^{* * *} \\
\text { CRANGs }^{* *+}+\mathrm{PERC}^{* * *}+\mathrm{SUN}^{* *}+\mathrm{CLUPS}^{* * *}+\mathrm{SCORPS}^{* * *}+\mathrm{DEBIETs}^{* *}+\mathrm{SALW}^{* * *}\end{array}$ & $\begin{array}{l}0.859 \\
0.863\end{array}$ & $\begin{array}{l}0.265 \\
0.283\end{array}$ & $\begin{array}{l}0.0000 \\
0.0000\end{array}$ \\
\hline 8 & 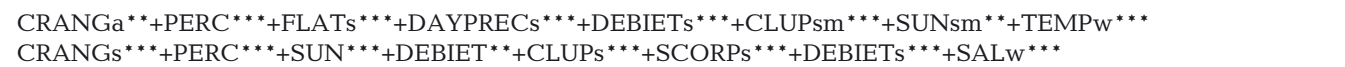 & $\begin{array}{l}0.897 \\
0.902\end{array}$ & $\begin{array}{l}0.206 \\
0.202\end{array}$ & $\begin{array}{l}0.0000 \\
0.0000\end{array}$ \\
\hline 9 & 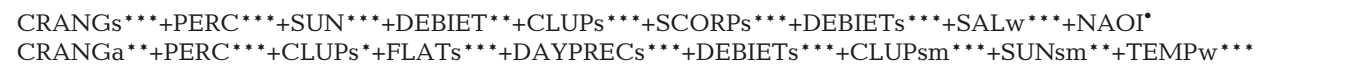 & 0.914 & $\begin{array}{l}0.185 \\
0.187\end{array}$ & $\begin{array}{l}0.0000 \\
0.0000\end{array}$ \\
\hline & 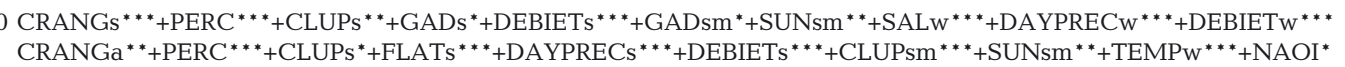 & $\begin{array}{l}0.930 \\
0.934\end{array}$ & $\begin{array}{l}0.165 \\
0.163\end{array}$ & $\begin{array}{l}0.0000 \\
0.0000\end{array}$ \\
\hline
\end{tabular}



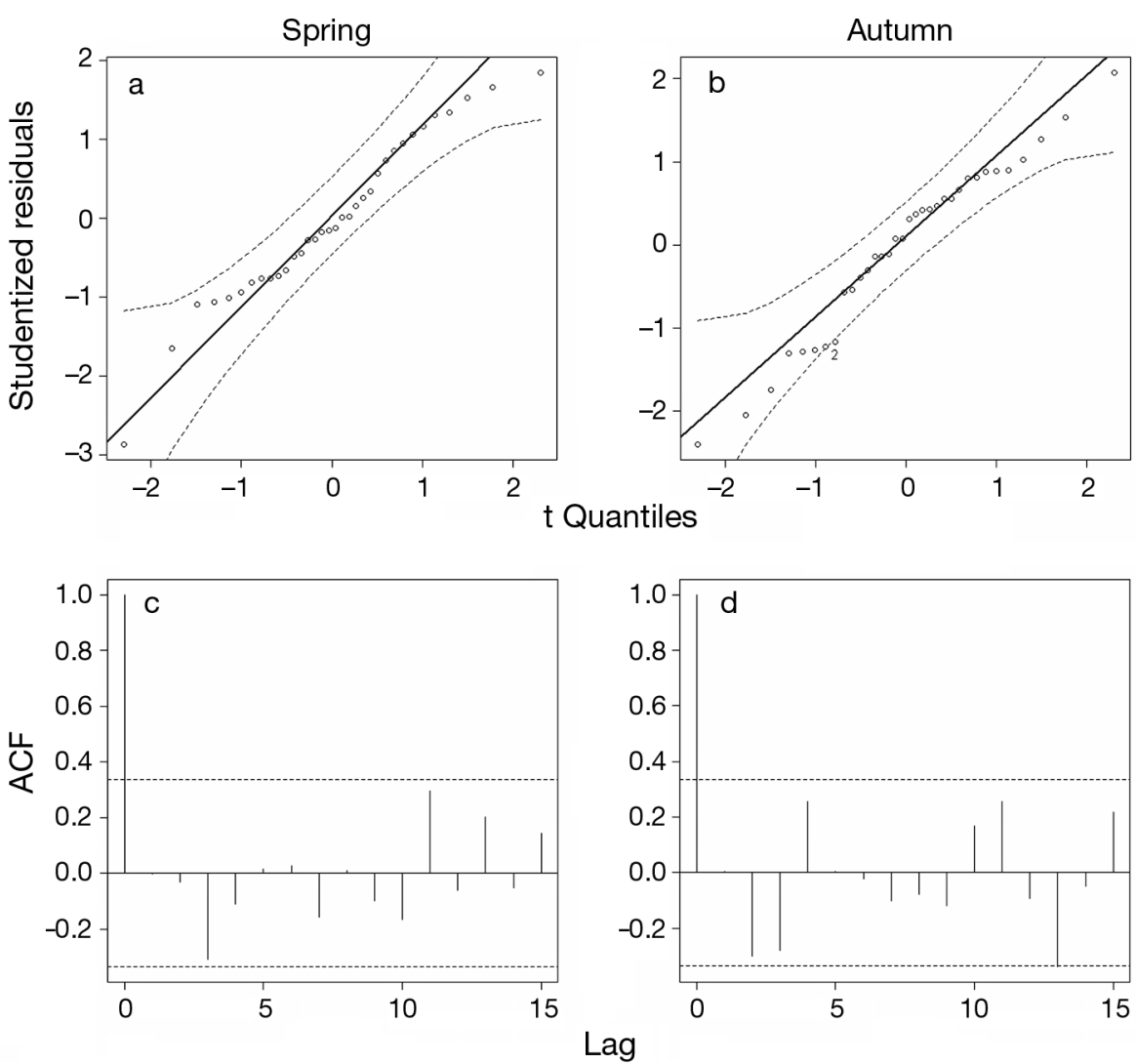

Fig. 5. QQ-plot of regression model residuals $(\mathrm{a}, \mathrm{b})$ and residual autocorrelation functions $(A C F ; \mathrm{c}, \mathrm{d})$ for the selected spring (left; $\log ($ CRANG $)=1.465+0.313 \log ($ CRANGa $)+0.878 \log ($ PERC $)-0.386$ TEMP $-0.611 \log (\mathrm{GADa})+0.312$ TEMPa $)$ and autumn $($ right $; \log ($ CRANG $)=9.588+2.265 \log ($ PERC $)+0.321 \log ($ CLUPs $)+0.172 \log ($ CLUPsm $)-0.438$ SALw -0.003 DEBIETw $)$ regression models. (O): residual; dashed line: $95 \%$ confidence limit; continuous line: $45^{\circ}$ reference line

ables included a pair of significantly, negatively correlated predictor variables, TEMP and GADa (-0.405).

\section{DISCUSSION}

\section{Long-term trends in annual abundance}

For the last $34 \mathrm{yr}$, despite large fluctuations, the abundance of adult Crangon crangon in the Dutch Wadden Sea shows an overall increasing trend. The ARMA prediction therefore showed a positive seasonal trend for the next $5 \mathrm{yr}$. However, there seems to be a decreasing trend in the stock size after 2000, which was not analysed separately as the available time series is presently too short for a sound time-series analysis of the divided data. Future monitoring will reveal whether brown shrimp abundance will recover from the recent downward trend. In the Bristol Channel, a general increasing trend was also found until 2005 (Henderson et al. 2006), while in the German Wadden Sea, no trend was found in brown shrimp den- sities between 1974 and 2002 (Siegel et al. 2005). Brown shrimp landings in the North Sea have also been increasing since the 1970s, despite a considerable decline from the mid to late 1980s of about one third of previous landings, and reached a maximum of 16000 t in 2006 (ICES 2008). However, it should be kept in mind that this increase in landings is also partly due to an increase in fishing effort (ICES 2008).

The increasing Crangon crangon abundance observed in the Dutch Wadden Sea, as well as in the Bristol Channel and in the North Sea landings, might reflect global warming effects as observed in fish species (Roessig et al. 2004, Rose 2005, Harley et al. 2006, Portner \& Knust 2007). For the past $25 \mathrm{yr}$ the mean annual water temperature at the entrance of the Dutch Wadden Sea has increased by about $1.5^{\circ} \mathrm{C}$ (van Aken 2008a). Such variation has complex effects at several levels, from organism physiology to ecosystem function, through trophic relationships (Freitas et al. 2007). A decline in total fish biomass in the area, from 1985 until early 2000, has already been reported (Tulp et al. 2008), suggesting a possible reduction in the overall 


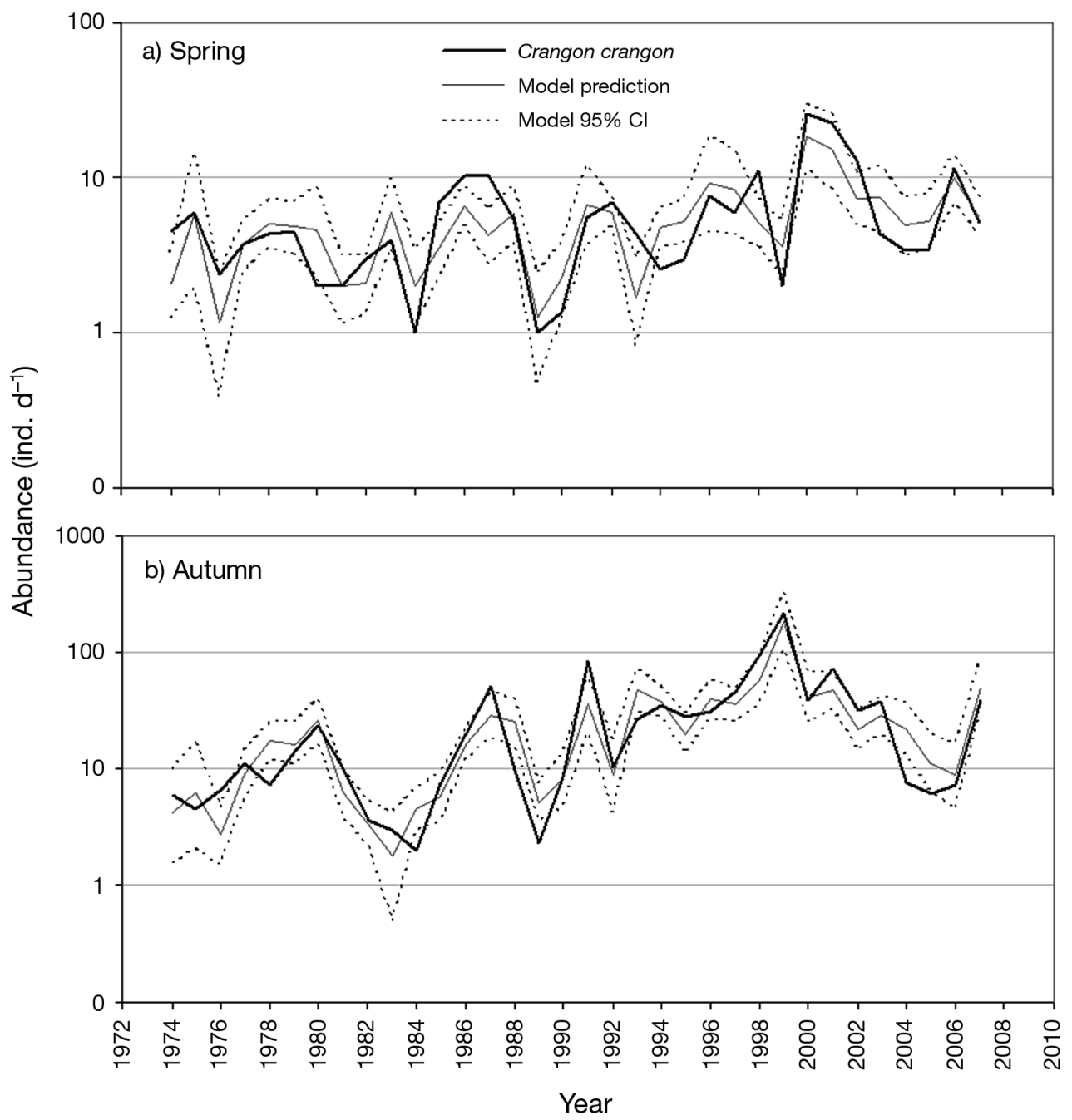

Fig. 6. Crangon crangon. (a) Spring and (b) autumn abundances in the Dutch Wadden Sea, regression model predictions and their $95 \%$ confidence intervals $(\mathrm{CI})$; spring model: $\log (\mathrm{CRANG})=1.465+0.313 \log (\mathrm{CRANGa})+0.878 \log (\mathrm{PERC})-0.386$ TEMP $0.611 \log (\mathrm{GADa})+0.312 \mathrm{TEMPa}$, and autumn model: $\log (\mathrm{CRANG})=9.588+2.265 \log (\mathrm{PERC})+0.321 \log (\mathrm{CLUPs})+0.172$ $\log ($ CLUPsm $)-0.438$ SALw - 0.003 DEBIETw

predation pressure on the C. crangon population, which favours its increased abundance. In the same way, the population might have benefited from the increased food availability due to rising water temperature. C. crangon is an opportunistic feeder with a very varied diet, mainly composed of demersal, in- and epifaunal organisms during its juvenile and adult life; during larval stages its diet probably consists of plankton (Campos \& van der Veer 2008). C. crangon is not particularly sensitive to pollution levels but the reduced nutrient loads reported from the 1970s onwards (van Raaphorst \& De Jonge 2004), might also contribute to changes in shrimp abundance. However, whether or not the nutrient reduction has caused a decrease in the productivity of the coastal waters is still under discussion (Cadee \& Hegeman 2002, Philippart et al. 2007).
In addition to the long-term increasing trend, seasonality in brown shrimp abundance was observed, with considerably lower (5 times) abundances in spring compared to autumn. This corroborates previous observations (Siegel et al. 2005, Henderson et al. 2006) reflecting shrimp production in the coastal zone (Kuipers \& Dapper 1984). Also, commercial landings are highest in autumn and lowest in spring (ICES 2008). Since the fyke mesh size $(10 \times 10 \mathrm{~mm})$ was too large to capture the small juveniles entering the Wadden Sea, the observed low spring abundance represents the adult shrimps which have overwintered offshore (Temming \& Damm 2002) and survived winter mortality. The large autumn abundance represents mature shrimps leaving the nurseries for the overwintering areas in the coastal zone. The variability of 
spring abundance was also lower than that of autumn abundance, as revealed by the deviation in relation to the mean (see Appendix). This is the opposite of what was found in the German area, where, although spring abundance is also lower than in autumn, autumn densities are relatively more stable in comparison to spring densities (Siegel et al. 2005).

Some peaks and lows in Crangon crangon abundance in the Dutch Wadden Sea coincided with or occurred close to those observed in time series from other sites: the 1987 autumn peak of the present study preceded the 1988 maximum observed in the Bristol Channel and followed the 1986 peak in the German Bight; the 2003 peak in the Dutch Wadden Sea followed the 2002 autumn maximum in the Bristol Channel; and the 1998 spring peak coincided in the Dutch and the German Wadden Sea. From 1976 to 1978, spring minima were registered both in the German and in the Dutch Wadden Sea; the 1983 and 1989/90 spring minima of the present study preceded respectively the 1984 and the 1991 minima in the German area. Other fluctuations did not correspond with the dynamics observed at the other 2 locations and might be related to local conditions. Regional variability has been detected in 3 areas of the German Bight with occasional opposing trends in abundance for the same year (Siegel et al. 2005).

\section{Seasonal trends in abundance}

The brown shrimp life cycle follows a seasonal pattern. At intermediate latitudes of distribution (within the 45 to $55^{\circ} \mathrm{N}$ latitudinal range) reproduction occurs in more saline waters throughout the entire year with spawning peaks in spring-summer and winter (Boddeke 1982, Kuipers \& Dapper 1984, Henderson \& Holmes 1987, Oh \& Hartnoll 2004). Pelagic larvae are found over almost the entire year (Lebour 1947, Kuhl \& Mann 1963, van der Baan 1975) though mostly from May to September (Plett 1965, Feddersen 1993), migrating into shallow nurseries often situated in estuaries. Hence, the bulk of larval settlement takes place in the warmer seasons (Kuipers \& Dapper 1981) and might contribute to the high autumn recruitment to fisheries (Kuipers \& Dapper 1984). Remarkably, over the period of scientific observation, Crangon crangon recruitment has been very successful. In the same way, in most years and across its geographic distribution, $C$. crangon is continuously highly abundant in shallow coastal areas (Campos \& van der Veer 2008).

Time-series and cross-correlation analyses revealed population effects with lags of up to 1 yr (i.e. 1 spring and 1 autumn season), which is consistent with Crangon crangon life history and lifespan of 1 to $3 \mathrm{yr}$ (Cam- pos \& van der Veer 2008). Given the short life span of the species, rapid seasonal changes in abundance could be expected with abrupt drops due to adverse environmental conditions and steep recoveries under favourable circumstances. Such rapid changes of abundance were observed in the present study in 1999: a spring minimum was followed by an autumn maximum in the same year. This was the maximum abundance and the greatest change observed in the entire time series.

\section{Factors affecting autumn abundance}

Apart from previous shrimp abundances (representing temporal autocorrelation), other variables were related with the size of the autumn recruit stock. As hypothesised, predator abundance was observed to consistently influence brown shrimp autumn abundance, explaining up to $85 \%$ of the variance in autumn models when considered altogether, reflecting their high importance. Predation and even cannibalism, which represents about $20 \%$ of the species annual food consumption (Pihl \& Rosenberg 1982), are known to be important causes of brown shrimp natural mortality (Henderson \& Holmes 1989), though fluctuations in predator abundance might be difficult to relate to Crangon crangon stock fluctuations (Henderson et al. 2006). Nevertheless, brown shrimp densities have been identified as one of the explanatory variables for the long-term trends in abundance of several fish species observed in Dutch waters (Tulp et al. 2008).

Concerning the predator groups, Clupeiforms, Perciforms, Scorpaeniforms, Pleuronectiforms and Decapods were the groups with the greatest influence in autumn, though the last 2 had 1 and 2 yr lag, respectively. Autumn Crangon crangon abundance was positively cross-correlated with the Clupeiforms, which comprised mostly herring Clupea harengus but also included twaite shad Alosa fallax, and was further related to the abundance of this group in the previous spring. Clupeiforms are planktivorous (Dalpadado et al. 2000) and do not feed on adult shrimps. The positive correlation between C. crangon and Clupeiform abundances suggests that they share environmental resources but do not compete. However, Clupeiforms might feed on $C$. crangon planktonic larvae, which would explain the time lag between autumn abundance and spring fish abundance. Perciforms were also positively cross-correlated with autumn abundance and a selected term in the models. In contrast, shrimp abundance was negatively related to Scorpaeniforms and Decapods, probably due to mortality losses by predation. The Decapod group only included the crab Carcinus maenas and was the second most 
abundant group in the entire time series, following the Clupeiforms, while the Scorpaeniform group was the least abundant predator group on average.

The environmental variables which were related to autumn brown shrimp abundances were (1) sunshine duration, (2) salinity, (3) out-flow from Lake IJssel into the Wadden Sea, and (4) the NAOI, the first 3 during winter. However, temperature conditions during the growing season (spring and summer) were not related to the autumn stock, contradicting Hypothesis 1. Autumn abundances were more closely related to previous winter conditions. Winter sunshine duration was positively correlated with autumn abundance, while salinity and out-flow from Lake IJssel, both from the previous winter, were negatively related to autumn stock. Winters with more saline conditions, probably associated with lower precipitation and out-flow from Lake IJssel, seem thus to favour autumn recruitment. Salinity directly affects brown shrimp ecophysiology and influences their migrations; it also indirectly influences the stock through changes in productivity and therefore food availability. Primary and secondary productivity effects were not tested, though their influence might also be related to sunshine duration and river run off. River discharge also affected the autumn recruitment in the Bristol Channel (Henderson et al. 2006) and in the German Bight (Siegel et al. 2005). Finally, the NAOI was only a relevant factor in the model when winter variables were included.

\section{Factors affecting spring abundance}

Crangon crangon adult stock in spring (recruits) was positively related to the previous autumn recruitment, but not to the adult stock in spring 1 yr earlier. This was expected since the spring population represents overwintering adults and thus belongs to the same generation as the previous autumn population. In addition, the abundance of predators was also very relevant in determining shrimp stock, though with less importance than in autumn, explaining up to $55 \%$ of the spring models' variance. This supports the hypothesis that shrimp abundance depends mainly on predator abundance, especially in autumn. Although the research hypothesis considered predation impact during winter, the fyke catch in this season might not correspond to the predators affecting shrimps in the overwintering areas since they migrate offshore.

Apart from Pleuronectiforms, the same groups which were related to autumn abundance also affected the stock in spring, but Clupeiforms were more important in spring and Perciforms in autumn. As in autumn, Clupeiforms were positively, whereas Scorpaeniforms and Decapods were negatively, related to shrimp abundance during spring. Finally, Gadiform abundance in autumn was included in the spring model and negatively related to Crangon crangon abundance. Despite including whiting Merlangius merlangus, a very abundant and important predator of brown shrimp (Henderson \& Holmes 1989, Henderson et al. 1992, Hamerlynck \& Hostens 1993, Singh-Renton \& Bromley 1999), Gadiforms did not show a significant cross-correlation with the Dutch Wadden Sea shrimp abundances, contradicting the observations in the German area (Siegel et al. 2005) and in the Bristol Channel (Henderson et al. 2006). However, the abundance of Gadiforms was correlated with the abundance of other predators especially Scorpaeniforms. The effect of Gadiforms is therefore possibly related to a confounding variable, such as other predators. Also, the strong correlation with temperature might interfere with its detection.

Environmental conditions correlated to brown shrimp spring abundances included (1) winter sunshine duration, (2) temperature, (3) autumn salinity and (4) the WNAOI (Table 1). While winter sunshine duration, temperature and salinity, both in autumn, were positively related to spring abundance, spring temperature and the WNAOI were negatively related. However, as in autumn, the WNAOI, which was previously considered important in the Bristol Channel (Henderson et al. 2006), only appeared to be relevant when the winter variables were included, accounting for $38 \%$ of the explained variance in the spring model.

The hypothesis established for the spring season considered only winter conditions. Yet only sunshine duration in winter was a significant determinant. Its positive relationship with brown shrimp stock size in spring and also in autumn suggests that mild winters with more clear days favour increases in the stock later in the year, which might be related to an overall increase in the productivity of the area. In contrast, after severe winters with lower mean sunshine duration, brown shrimp abundance declines and they might even be practically absent, as has been observed previously on the Wadden Sea tidal flats (Beukema 1992). This confirms the hypothesis that spring abundance (related to overwintering survival) is determined by the severity of winter conditions, probably due to direct consequences of temperature and, indirectly, to variations in food availability and predation pressure. Nevertheless, in the present study, winter sunshine duration was not correlated with any other winter environmental variable, such as temperature.

In conclusion, over the last $34 \mathrm{yr}$, a general increasing trend in the abundance of Crangon crangon in the western Dutch Wadden Sea was observed, which is consistent with trends observed in other areas and reported by fisheries. Autumn abundance was 5 times 
higher than spring abundance and presented more pronounced variability, which conforms to the brown shrimp life cycle. The abundance of adults in autumn was positively related to predator abundance, while the abundance of overwintering adults in spring was related to the severity of winter conditions in addition to predation pressure. The chosen multiple regression models for the spring and autumn time series fitted the data very well, especially the autumn models which explained up to $90.9 \%$ of the variance. Less or more complex models could have been chosen, and also different models of the same complexity, as some of the biotic and abiotic variables available for regression modelling are correlated and may produce similar levels of fit in a multiple regression model. Variables may also interact, and inclusion of interaction terms might have improved our models. It will be interesting to validate the selected and alternative models on future brown shrimp data which continue to be sampled. More data will allow a better insight into the effects of climate variables and predation pressure on brown shrimp abundances and confirm or refute the recent downward trend in the shrimp population.

Acknowledgements. The authors thank M. Boos, P. Henderson, I. Tulp and A. Rijnsdorp for critical comments on a previous version of this manuscript. P. Henderson revised the English and I. Tulp provided data on shrimp commercial landings. This work was supported by a grant from Iceland, Liechtenstein and Norway through the EEA Financial Mechanism and the Norwegian Financial Mechanism. J.F.M.F.C. is supported by the Postdoc grant SFRH/BPD/34773/2207 from FCT, Portugal.

\section{LITERATURE CITED}

Amara R, Paul C (2003) Seasonal patterns in the fish and epibenthic crustaceans community of an intertidal zone with particular reference to the population dynamics of plaice and brown shrimp. Estuar Coast Shelf Sci 56: 807-818

Ansell AD, Gibson RN (1993) The effect of sand and light on predation of juvenile plaice (Pleuronectes platessa) by fishes and crustaceans. J Fish Biol 43:837-845

Attrill MJ, Power M, Thomas RM (1999) Modelling estuarine Crustacea population fluctuations in response to physicochemical trends. Mar Ecol Prog Ser 178:89-99

Berghahn R (1996) Episodic mass invasions of juvenile gadoids into the Wadden Sea and their consequences for the population dynamics of brown shrimp (Crangon crangon). PSZNI: Mar Ecol 17:251-260

Beukema JJ (1979) Biomass and species richness of the macrobenthic animals living on a tidal flat area in the Dutch Wadden Sea: effects of a severe winter. Neth J Sea Res 13: 203-223

Beukema JJ (1992) Dynamics of juvenile shrimp Crangon crangon in a tidal-flat nursery of the Wadden Sea after mild and cold winters. Mar Ecol Prog Ser 83:157-165

Boddeke R (1968) Forecasting the landings of brown shrimp (Crangon crangon) in The Netherlands. ICES (Shelfish and Benthos Committtee), CM 1968/K:8
Boddeke R (1975) Autumn migration and vertical distribution of the brown shrimp Crangon crangon L. in relation to environmental conditions. In: Barnes $\mathrm{H}$ (ed) Proc 9th Eur Mar Biol Symp, 2-8 Oct 1974. Aberdeen University Press, Aberdeen, p 483-494

Boddeke R (1976) The seasonal migration of the brown shrimp Crangon crangon. Neth J Sea Res 10:103-130

Boddeke R (1982) The occurrence of winter and summer eggs in the brown shrimp (Crangon crangon) and the pattern of recruitment. Neth J Sea Res 16:151-162

Boddeke R, Becker HB (1979) A quantitative study of the fluctuations of the stock of brown shrimp (Crangon crangon) along the coast of The Netherlands. Rapp P-V Réun Cons Int Explor Mer 175:253-258

Boddeke R, Dijkema R, Siemelink ME (1976) The patterned migration of shrimp populations: a comparative study of Crangon crangon and Penaeus brasiliensis. FAO Fish Rep 200:31-49

Brockwell PJ, Davis RA (1996) Introduction to time-series and forecasting. Springer, New York

Broekema MMM (1942) Seasonal movements and the osmotic behaviour of the shrimp Crangon crangon L. Arch Neerl Zool 6:1-100

Cadee GC, Hegeman J (2002) Phytoplankton in the Marsdiep at the end of the 20th century; 30 years monitoring biomass, primary production, and Phaeocystis blooms. J Sea Res 48:97-110

Campos J, van der Veer HW (2008) Autecology of Crangon crangon (L.) with an emphasis on latitudinal trends. Oceanogr Mar Biol Annu Rev 46:65-104

Cattrijsse A, Dankwa HR, Mees J (1997) Nursery function of a tidal marsh for the brown shrimp Crangon crangon. J Sea Res 38:109-121

Dalpadado P, Ellertsen B, Melle W, Dommasnes A (2000) Food and feeding conditions of Norwegian springspawning herring (Clupea harengus) through its feeding migrations. ICES J Mar Sci 57:843-857

del Norte-Campos AGC, Temming A (1994) Daily activity, feeding and rations in gobies and brown shrimp in the northern Wadden Sea. Mar Ecol Prog Ser 115:41-53

$>$ del Norte-Campos AGC, Temming A (1998) Population dynamics of the brown shrimp Crangon crangon L., in shallow areas of the German Wadden Sea. Fish Manag Ecol 5:303-322

> De Vlas J (1979) Annual food intake by plaice and flounder in a tidal flat area in the Dutch Wadden Sea, with special reference to consumption of regenerating parts of macrobenthic prey. Neth J Sea Res 13:117-153

Driver PA (1976) Prediction of fluctuations in the landings of brown shrimp (Crangon crangon) in the Lancashire and Western Sea Fisheries District. Estuar Coast Mar Sci 4: 567-573

Ehrenbaum E (1890) Zur Naturgeschichte von Crangon vulgaris Fabr. Dt Seefisch-Verein, Mittl Sekt Küsten Hochseefisch, Sonderbeilage:9-124

Feddersen U (1993) Eine vergleichende Studie über Zooplanktonvorkommen im Nordfriesischen Wattenmeer. Diplomarbeit, Hamburg University

Freitas V, Campos J, Fonds M, van der Veer HW (2007) Potential impact of temperature change on epibenthic predator-bivalve prey interactions in temperate estuaries. J Therm Biol 32:328-340

Hamerlynck O, Hostens K (1993) Growth, feeding, production, and consumption in 0-group bib (Trisopterus luscus L.) and whiting (Merlangius merlangus L.) in a shallow coastal area of the south-west Netherlands. ICES J Mar Sci 50:81-91 
Harley CDG, Hughes AR, Hultgren KM, Miner BG and others (2006) The impacts of climate change in coastal marine systems. Ecol Lett 9:228-241

Havinga B (1930) Der Granat (Crangon vulgaris Fabr.) in den hollandischen Gewassern. J Cons Int Explor Mer 5:57-87

Henderson PA, Holmes HA (1987) On the population biology of the common shrimp Crangon crangon (L.) (Crustacea: Caridea) in the Severn Estuary and Bristol Channel. J Mar Biol Assoc UK 67:825-847

Henderson PA, Holmes HA (1989) Whiting migration in the Bristol Channel: a predator-prey relationship. J Fish Biol 34:409-416

Henderson PA, James D, Holmes RHA (1992) Trophic structure within the Bristol Channel: seasonality and stability in Bridgewater Bay. J Mar Biol Assoc UK 72:675-690

> Henderson PA, Seaby RM, Somes JR (2006) A 25-year study of climatic and density-dependent population regulation of common shrimp Crangon crangon (Crustacea:Caridea) in the Bristol Channel. J Mar Biol Assoc UK 86:287-298

> Hurvich CM, Tsai CL (1989) Regression and time series model selection in small samples. Biometrika 76:297-307

Hyndman RJ (1994) ITSM for Windows. Springer, USA

ICES (2008) Report of the Working Group on Crangon Fisheries and Life History (WGCRAN). Texel, The Netherlands. ICES CM 2008/LRC 12:1-49

Jones PD, Jonsson T, Wheeler D (1997) Extension to the North Atlantic Oscillation using instrumental pressure observations from Gibraltar and South-West Iceland. Int J Climatol 17:1433-1450

Kuhl H, Mann H (1963) On the distribution of shrimp larvae (Crangon crangon L.) in the estuary of the Elbe. Veröff Inst Küst Binnenfisch 27:50-52

Kuipers BR, Dapper R (1981) Production of Crangon crangon in the tidal zone of the Dutch Wadden Sea. Neth J Sea Res 15:33-53

Kuipers BR, Dapper R (1984) Nursery function of Wadden Sea tidal flats for the brown shrimp Crangon crangon. Mar Ecol Prog Ser 17:171-181

Lebour MV (1947) Notes on the inshore plankton of Plymouth. J Mar Biol Assoc UK 26:239-252

Lindeman RH, Merenda PF, Gold RZ (1980) Introduction to bivariate and multivariate analysis. Scott, Foresman, Glenview, IL

Lloyd AJ, Yonge CM (1947) The biology of Crangon vulgaris L. in the Bristol Channel and the Severn estuary. J Mar Biol Assoc UK 26:626-661

Luttikhuizen PC, Campos J, Bleijswijk J, Peijnenburg KTCA, van der Veer HW (2008) Phylogeography of the common shrimp, Crangon crangon (L.) in European waters. Mol Phylogenet Evol 46:1015-1030

McCullagh P, Nelder JA (1983) Generalized linear models. Chapman \& Hall, London

Miller A (2002) Subset selection in regression, 2nd edn. Chapman \& Hall/CRC, Boca Raton, FL

Nédélec C (1982) Definition and classification of fishing gear categories. FAO Fish Tech Pap 222

> Oh CW, Hartnoll RG (2004) Reproductive biology of the common shrimp Crangon crangon (Decapoda: Crangonidae) in the central Irish Sea. Mar Biol 144:303-316

Oh CW, Hartnoll RG, Nash RDM (2001) Feeding ecology of the common shrimp Crangon crangon in Port Erin Bay, Isle of Man, Irish Sea. Mar Ecol Prog Ser 214:211-223

Philippart CJM, Beukema JJ, Cadeé GC, Dekker R and others (2007) Impacts of nutrient reduction on coastal communities. Ecosystems 10:96-119

Pihl L (1985) Food selection and consumption of mobile epibenthic fauna in shallow marine areas. Mar Ecol Prog
Ser 22:169-179

Pihl L, Rosenberg R (1982) Production, abundance and biomass of mobile epibenthic marine fauna in shallow waters, western Sweden. J Exp Mar Biol Ecol 57:273-301

Pihl L, Rosenberg R (1984) Food selection and consumption of the shrimp Crangon crangon in some shallow marine areas in western Sweden. Mar Ecol Prog Ser 15:159-168

Plett A (1965) Uber das Vorkommen von Garnelenlarven (Crangon crangon L.) vor der deutschen Küste in den Jahren 1963 und 1964. Arch FischWiss 16:54-67

Pörtner HO, Knust R (2007) Climate change affects marine fishes through the oxygen limitation of thermal tolerance. Science 315:95-97

Polet H (2002) Selectivity experiments with sorting grids in the North Sea brown shrimp (Crangon crangon) fishery. Fish Res 54:217-233

R Development Core Team (2005) R: A language and environment for statistical computing. R Foundation for Statistical Computing, Vienna

> Roessig JM, Woodley CM, Cech JJ, Hansen LJ (2004) Effects of global climate change on marine and estuarine fishes and fisheries. Rev Fish Biol Fish 14:251-275

> Rose GA (2005) On distributional responses of North Atlantic fish to climate change. ICES J Mar Sci 62:1360-1374

> Siegel V, Gröger J, Neudecker T, Damm U, Jansen S (2005) Long-term variation in the abundance of the brown shrimp Crangon crangon (L.) population of the German Bight and possible causes for its interannual variability. Fish Oceanogr 14:1-16

Singh-Renton S, Bromley PJ (1999) Feeding of small whiting (Merlangius merlangus) in the central and southern North Sea. J Mar Biol Assoc UK 79:957-960

Spaargaren DH (2000) Seasonal and annual variations in the catches of Crangon crangon (L., 1758) (Decapoda, Natantia) near the coast of Texel, The Netherlands. Crustaceana 73:547-563

Temming A, Damm U (2002) Life cycle of Crangon crangon in the North Sea: a simulation of the timing of recruitment as a function of the seasonal temperature signal. Fish Oceanogr 11:45-58

Tiews K (1970) Synopsis of biological data on the common shrimp Crangon crangon (Linnaeus, 1758). FAO Fish Rep 57:1167-1224

Tulp I, Bolle LJ, Rijnsdorp AD (2008) Signals from the shallows: In search of common patterns in long-term trends in Dutch estuarine and coastal fish. J Sea Res 60:54-73

van Aken HM (2008a) Variability of the water temperature in the western Wadden Sea on tidal to centennial time scales. J Sea Res 60:227-234

van Aken HM (2008b) Variability of the salinity in the western Wadden Sea on tidal to centennial time scales. J Sea Res 59:121-132

van der Baan SM (1975) Migration of Crangon crangon in surface waters near the 'Texel' lightship. Neth J Sea Res 9: $287-296$

van der Hoeven PCT (1982) Observations of surface water temperature and salinity, State Office of Fishery Research (RIVO): 1860-1981. KNMI Scientific Report WR 82-8. KNMI, De Bilt

van der Meer J, Witte IIJ, van der Veer HW (1995) The suitability of a single intertidal fish trap for the assessment of long-term trends in fish and epibenthic invertebrate populations. Environ Monit Assess 36:139-148

> van der Veer HW, Bergman MJN, Dapper R, Witte JIJ (1991) Population dynamics of an intertidal 0-group flounder Platichthys flesus population in the western Dutch Wadden Sea. Mar Ecol Prog Ser 73:141-148 
van der Veer HW, Witte JIJ, Beumkes HA, Dapper R, Jongejan WP, van der Meer J (1992) Intertidal fish traps as a tool to study long-term trends in juvenile flatfish populations. Neth J Sea Res 29:119-126

van der Veer HW, Feller RJ, Weber A, Witte JIJ (1998) Importance of predation by crustaceans upon bivalve spat in the intertidal zone of the Dutch Wadden Sea as revealed by immunological assays of gut contents. J Exp Mar Biol Ecol 231:139-157 van Raaphorst W, De Jonge VN (2004) Reconstruction of the total $\mathrm{N}$ and $\mathrm{P}$ inputs from the IJsselmeer into the Western Wadden Sea between 1935-1998. J Sea Res 51: 109-131

Walter U, Becker PH (1997) Occurrence and consumption of seabirds scavenging on shrimp trawler discards in the Wadden Sea. ICES J Mar Sci 54:684-694

Welleman HC, Daan N (2001) Is the Dutch shrimp fishery sustainable? Senckenb Marit 31:321-328

Appendix 1. List of variable codes, description and minimum, maximum, median, mean and standard deviation (SD) of all variables for spring and autumn datasets. Outflow: Lake IJssel outflow into the Wadden Sea $\left(\mathrm{m}^{3} \mathrm{~s}^{-1}\right)$

\begin{tabular}{|c|c|c|c|c|c|c|c|c|c|c|c|}
\hline \multirow{2}{*}{ Code } & \multirow{2}{*}{ Description } & \multicolumn{5}{|c|}{ - Spring- } & \multicolumn{5}{|c|}{-Autumn- } \\
\hline & & $\operatorname{Max}$ & Min & Median & Mean & $\mathrm{SD}$ & Max & Min & Median & Mean & $\mathrm{SD}$ \\
\hline \multicolumn{12}{|c|}{ Daily abundance } \\
\hline \multicolumn{12}{|c|}{ Crangon crangon } \\
\hline CRANG & Current season & 25.38 & 0.00 & 4.43 & 6.14 & 5.49 & 220.14 & 2.00 & 12.71 & 29.61 & 41.06 \\
\hline CRANGs & Previous spring & 25.38 & 0.00 & 4.34 & 5.99 & 5.59 & 25.38 & 0.00 & 4.43 & 6.14 & 5.49 \\
\hline CRANGa & Previous autumn & 220.14 & 0.10 & 10.78 & 28.48 & 41.33 & 220.14 & 0.00 & 10.78 & 28.48 & 41.33 \\
\hline \multicolumn{12}{|c|}{ Clupeiforms } \\
\hline CLUP & Current season & 188.78 & 3.24 & 20.88 & 35.48 & 39.25 & 686.39 & 12.52 & 127.11 & 200.50 & 170.06 \\
\hline CLUPs & Previous spring & & & 188.78 & 3.24 & 20.88 & 35.48 & 39.25 & & & \\
\hline CLUPsm & Previous summer & & & 2623.98 & 3.25 & 72.66 & 189.03 & 472.56 & & & \\
\hline CLUPa & Previous autumn & 686.39 & 12.52 & 124.66 & 190.39 & 170.15 & & & & & \\
\hline CLUPw & Previous winter & 294.23 & 0.00 & 2.47 & 20.24 & 68.69 & 294.23 & 0.00 & 2.47 & 20.24 & 68.69 \\
\hline \multicolumn{12}{|l|}{ Gadiforms } \\
\hline GAD & Current season & 19.64 & 4.49 & 8.01 & 9.09 & 4.06 & 34.10 & 3.34 & 8.29 & 10.26 & 6.25 \\
\hline GADs & Previous spring & & & 19.64 & 4.49 & 8.01 & 9.09 & 4.06 & & & \\
\hline GADsm & Previous summer & & & 31.92 & 1.00 & 6.44 & 8.86 & 7.72 & & & \\
\hline GADa & Previous autumn & 34.10 & 3.34 & 8.29 & 10.23 & 6.28 & & & & & \\
\hline GADw & Previous winter & 13.77 & 0.00 & 3.49 & 4.54 & 4.03 & 13.77 & 0.00 & 3.49 & 4.54 & 4.03 \\
\hline \multicolumn{12}{|l|}{ Perciforms } \\
\hline PERC & Current season & 16.31 & 3.00 & 5.05 & 5.23 & 2.34 & 16.31 & 3.22 & 6.46 & 6.60 & 2.32 \\
\hline PERCs & Previous spring & & & 16.31 & 2.20 & 4.01 & 4.48 & 2.34 & & & \\
\hline PERCsm & Previous summer & & & 13.07 & 1.00 & 4.47 & 4.93 & 2.44 & & & \\
\hline PERCa & Previous autumn & 16.31 & 3.22 & 6.37 & 6.56 & 2.32 & & & & & \\
\hline PERCW & Previous winter & 6.00 & 0.00 & 1.79 & 2.30 & 2.18 & 6.00 & 0.00 & 1.79 & 2.30 & 2.18 \\
\hline \multicolumn{12}{|c|}{ Scorpaeniforms } \\
\hline SCORP & Current season & 26.52 & 1.00 & 2.17 & 3.07 & 4.29 & 7.42 & 1.00 & 2.33 & 2.76 & 1.56 \\
\hline SCORPs & Previous spring & & & 26.52 & 1.00 & 2.17 & 3.07 & 4.29 & & & \\
\hline SCORPsm & Previous summer & & & 7.03 & 0.00 & 1.00 & 1.19 & 1.59 & & & \\
\hline SCORPa & Previous autumn & 7.42 & 1.00 & 2.38 & 2.77 & 1.55 & & & & & \\
\hline SCORPw & Previous winter & 6.50 & 0.00 & 2.11 & 2.11 & 1.50 & 6.50 & 0.00 & 2.11 & 2.11 & 1.50 \\
\hline \multicolumn{12}{|c|}{ Pleuronectiforms } \\
\hline FLAT & Current season & 39.02 & 7.62 & 11.70 & 14.84 & 7.74 & 20.70 & 5.17 & 9.01 & 10.01 & 3.53 \\
\hline FLATs & Previous spring & & & 39.02 & 7.62 & 11.70 & 14.84 & 7.74 & & & \\
\hline FLATsm & Previous summer & & & 29.71 & 3.78 & 12.27 & 12.97 & 5.88 & & & \\
\hline FLATa & Previous autumn & 20.70 & 5.17 & 9.15 & 10.07 & 3.51 & & & & & \\
\hline FLATw & Previous winter & 101.50 & 0.00 & 5.06 & 12.84 & 23.52 & 101.50 & 0.00 & 5.06 & 12.84 & 23.52 \\
\hline \multicolumn{12}{|l|}{ Decapods } \\
\hline CRAB & Current season & 926.96 & 8.29 & 391.62 & 379.12 & 222.15 & 495.14 & 49.92 & 118.76 & 144.31 & 90.54 \\
\hline CRABs & Previous spring & & & 926.96 & 8.29 & 391.62 & 379.12 & 222.15 & & & \\
\hline CRABsm & Previous summer & & & 1999.41 & 16.62 & 202.91 & 353.51 & 432.93 & & & \\
\hline CRABw & Previous winter & 211.33 & 0.00 & 20.25 & 55.17 & 68.62 & 211.33 & 0.00 & 20.25 & 55.17 & 68.62 \\
\hline \multicolumn{12}{|c|}{ Water temperature $\left({ }^{\circ} \mathbf{C}\right)$} \\
\hline TEMP & Current season & 14.24 & 10.60 & 11.91 & 11.96 & 0.95 & 14.77 & 10.70 & 12.17 & 12.45 & 0.91 \\
\hline TEMPs & Previous spring & & & 14.24 & 10.60 & 11.91 & 11.96 & 0.95 & & & \\
\hline TEMPsm & Previous summer & & & 20.07 & 16.30 & 18.05 & 18.14 & 1.04 & & & \\
\hline TEMPa & Previous autumn & 14.77 & 10.70 & 12.17 & 12.44 & 0.91 & & & & & \\
\hline TEMPw & Previous winter & 6.48 & 0.51 & 4.35 & 4.30 & 1.37 & 6.48 & 0.51 & 4.35 & 4.30 & 1.37 \\
\hline
\end{tabular}


Appendix 1 (continued)

\begin{tabular}{|c|c|c|c|c|c|c|c|c|c|c|c|}
\hline \multirow[t]{2}{*}{ Code } & \multirow[t]{2}{*}{ Description } & \multicolumn{5}{|c|}{ - Spring- } & \multirow[b]{2}{*}{ Max } & \multirow{2}{*}{$\overline{M i n}$} & Autumn & \multirow{2}{*}{ Mean } & \multirow[b]{2}{*}{$\mathrm{SD}$} \\
\hline & & Max & Min & Median & Mean & $\mathrm{SD}$ & & & Median & & \\
\hline \multicolumn{12}{|l|}{ Salinity } \\
\hline SAL & Current season & 30.93 & 24.33 & 28.04 & 28.08 & 1.69 & 31.04 & 25.68 & 28.95 & 28.82 & 1.09 \\
\hline SALs & Previous spring & & & 30.93 & 24.33 & 28.04 & 28.08 & 1.69 & & & \\
\hline SALsm & Previous summer & & & 33.50 & 25.40 & 29.10 & 29.14 & 1.47 & & & \\
\hline SALa & Previous autumn & 31.04 & 25.68 & 29.00 & 28.86 & 1.08 & & & & & \\
\hline SALw & Previous winter & 29.25 & 24.74 & 26.99 & 26.95 & 0.94 & 29.25 & 24.74 & 26.99 & 26.95 & 0.94 \\
\hline \multicolumn{12}{|c|}{ Sun duration (h) } \\
\hline SUN & Current season & 7.69 & 4.79 & 6.41 & 6.25 & 0.81 & 5.07 & 2.41 & 3.36 & 3.47 & 0.61 \\
\hline SUNs & Previous spring & & & 7.69 & 4.79 & 6.41 & 6.25 & 0.81 & & & \\
\hline SUNsm & Previous summer & & & 9.78 & 5.35 & 6.77 & 6.94 & 1.15 & & & \\
\hline SUNa & Previous autumn & 5.07 & 2.41 & 3.35 & 3.46 & 0.61 & & & & & \\
\hline SUNw & Previous winter & 3.74 & 1.73 & 2.59 & 2.66 & 0.50 & 3.74 & 1.73 & 2.59 & 2.66 & 0.50 \\
\hline \multicolumn{12}{|c|}{ Total daily precipitation $(0.1 \mathrm{~mm})$} \\
\hline DAYPREC & Current season & 2.42 & 0.49 & 1.63 & 1.53 & 0.42 & 5.33 & 1.67 & 2.86 & 2.92 & 0.83 \\
\hline DAYPRECs & Previous spring & & & 2.42 & 0.49 & 1.63 & 1.53 & 0.42 & & & \\
\hline DAYPRECsm & Previous summer & & & 4.50 & 0.37 & 1.85 & 2.10 & 1.07 & & & \\
\hline DAYPRECa & Previous autumn & 5.33 & 1.67 & 2.92 & 2.94 & 0.81 & & & & & \\
\hline DAYPRECW & Previous winter & 3.01 & 0.94 & 1.93 & 1.91 & 0.55 & 3.01 & 0.94 & 1.93 & 1.91 & 0.55 \\
\hline \multicolumn{12}{|c|}{ Outflow $\left(\mathrm{m}^{3} \mathrm{~s}^{-1}\right)$} \\
\hline DEBIET & Current season & 390.74 & 65.78 & 220.23 & 224.57 & 81.52 & 630.00 & 119.38 & 237.20 & 255.46 & 100.74 \\
\hline DEBIETs & Previous spring & & & 390.74 & 65.78 & 220.23 & 224.57 & 81.52 & & & \\
\hline DEBIETsm & Previous summer & & & 292.45 & 0.00 & 134.10 & 144.78 & 70.07 & & & \\
\hline DEBIETa & Previous autumn & 630.00 & 119.38 & 239.00 & 262.43 & 107.64 & & & & & \\
\hline DEBIETw & Previous winter & 926.75 & 168.19 & 364.12 & 394.35 & 134.04 & 926.75 & 168.19 & 364.12 & 394.35 & 134.04 \\
\hline \multicolumn{12}{|c|}{ Annual landings } \\
\hline LANDINGS & Previous year & 16141.65 & 3998.90 & 7252.44 & 9036.12 & 3809.45 & & & & & \\
\hline LANDINGS & Current year & & & 16141.65 & 3998.90 & 7394.07 & 9335.57 & 3955.15 & & & \\
\hline \multicolumn{12}{|c|}{ North Atlantic Oscillation Index } \\
\hline NAOI & Current season & 1.39 & -0.96 & 0.02 & 0.08 & 0.52 & 1.81 & -1.14 & -0.09 & -0.05 & 0.64 \\
\hline WNAOI & Winter NAOI & 1.67 & -0.78 & 0.41 & 0.34 & 0.58 & 1.67 & -0.78 & 0.41 & 0.34 & 0.58 \\
\hline exWNAOI & Extended Winter NAOI & 1.41 & -0.99 & 0.35 & 0.29 & 0.56 & 1.41 & -0.99 & 0.35 & 0.29 & 0.56 \\
\hline
\end{tabular}

Editorial responsibility: Otto Kinne, Oldendorf/Luhe, Germany
Submitted: September 17, 2009; Accepted: January 13, 2010 Proofs received from author(s): April 7, 2010 